\title{
Domestic Debt and Sovereign Defaults
}

Enrico Mallucci
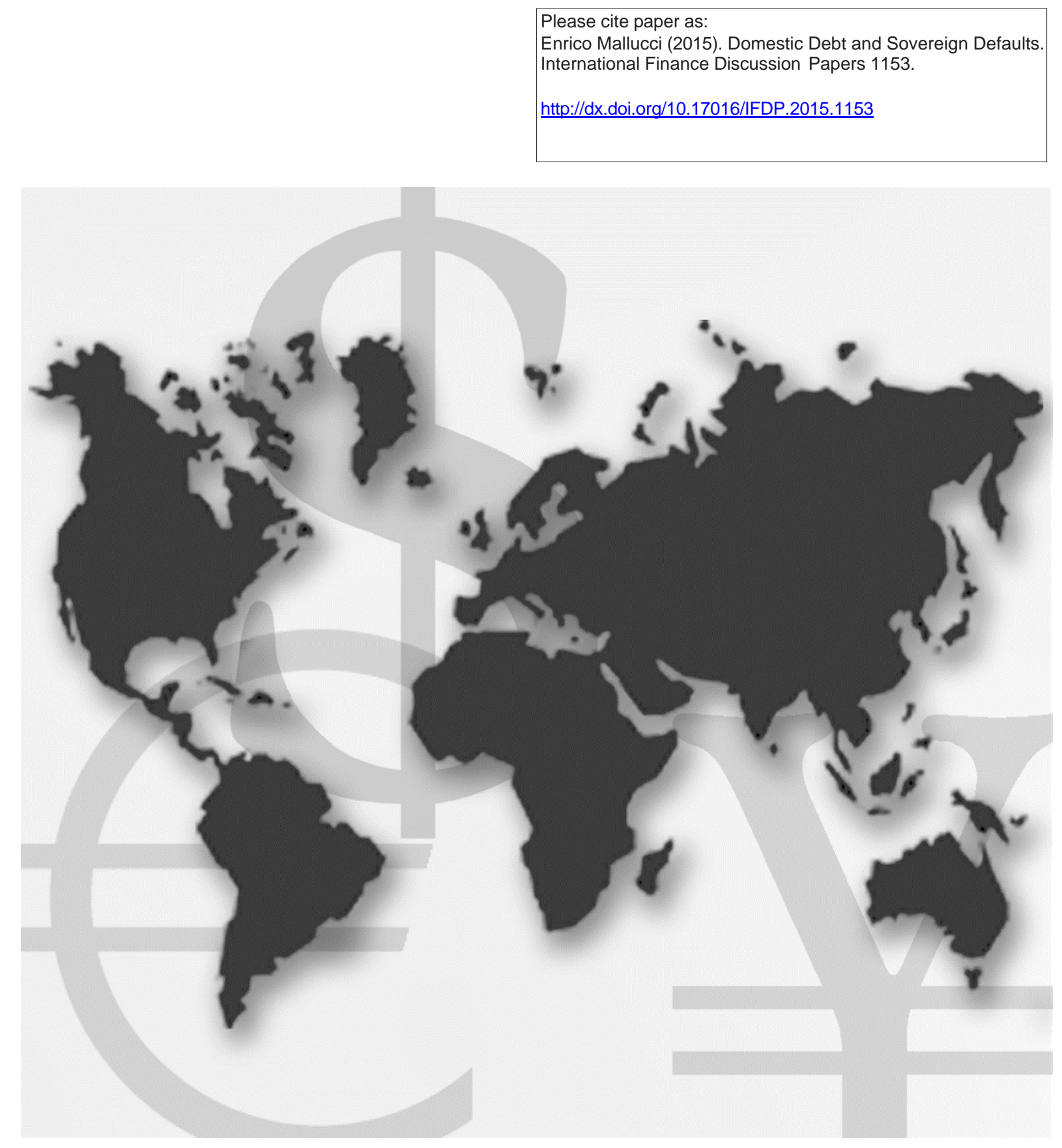

\section{International Finance Discussion Papers}

Board of Governors of the Federal Reserve System

Number 1153

December 2015 
Board of Governors of the Federal Reserve System

International Finance Discussion Paper

Number 1153

December 2015

\title{
Domestic Debt and Sovereign Defaults
}

\author{
Enrico Mallucci
}

NOTE: International Finance Discussion Papers are preliminary materials circulated to stimulate discussion and critical comment. References to International Finance Discussion Papers (other than an acknowledgment that the writer has had access to unpublished material) should be cleared with the author or authors. Recent IFDPs are available on the Web at www.federalreserve.gov/pubs/ifdp/. This paper can be downloaded without charge from the Social Science Research Network electronic library at www.ssrn.com. 



\title{
Domestic Debt and Sovereign Defaults
}

\author{
Enrico Mallucci*
}

\begin{abstract}
This paper examines how domestic holdings of government debt affect sovereign default risk and government debt management. I develop a dynamic stochastic general equilibrium model with both external and domestic debt that endogenously generates output contraction upon default. Domestic holdings of government debt weaken investors' balance sheets and induce a contraction of credit and output upon default. I calibrate the model to the Argentinean economy and show that the model reproduces key empirical moments. Introducing domestic debt also yields relevant normative implications. While domestic debt is crucial to determining the risk of default, the efficient internal-external composition of debt cannot be achieved without government intervention. Pigouvian subsidies can restore efficiency.
\end{abstract}

JEL classification: F34, F41, H63.

Keywords: Sovereign Defaults, Domestic Debt, Debt Crises, Credit Market.

*Board of Governors of the Federal Reserve System, Washington, D.C. 20551 U.S.A.. E-mail: enrico.mallucci@frb.gov.

The views in this paper are solely the responsibility of the author and should not be interpreted as reflecting the views of the Board of Governors of the Federal Reserve System or of any other person associated with the Federal Reserve System.

I would like to thank Gianluca Benigno and Keyu Jin for their support and advice, and Cristina Arellano, Nicola Gennaioli, Kevin Sheedy, and participants at the LSE brown bag seminar, 7th FIW Research Conference, and XVIII Workshop in International Economics and Finance for comments and suggestions. 


\section{Introduction}

Understanding why countries default is central to studying the sustainability of government debt. The scholarly literature has focused on two factors to explain default episodes: external debt size and business cycle fluctuations. Equally important, however, is the internal-external composition of debt. ${ }^{1}$ Reinhart and Rogoff (2008) highlight the importance of domestic debt. They study domestic debt dynamics from 1914 to 2007 in a sample of 64 countries and find a "forgotten history of domestic debt". While domestic debt is relevant to understand sovereign default episodes, very little research has been devoted to it. My paper fills this gap in the literature by incorporating domestic debt in the sovereign default literature.

Four key empirical regularities demonstrate the importance of domestic debt. (i) Domestic debt is large and constitutes the largest fraction of government debt. (ii) Contrary to conventional wisdom, domestic lenders are not junior to external lenders. Outright defaults on domestic debt happen frequently. (iii) Output contracts more around domestic defaults than around external defaults (iv), as does credit. Based on these regularities pertaining to domestic debt, I construct a dynamic stochastic general equilibrium model with endogenous default risk á la Eaton and Gersovitz (1981) that incorporates domestic debt and thereby rationalizes the four empirical regularities.

The theoretical model is composed of four sectors: a benevolent government, households, firms, and international investors. Households purchase domestic bonds and use them to store liquidity. As in Holmstrom and Tirole (1998) and Gennaioli et al. (2014), liquidity from the maturing bonds is transferred from households to firms that are subject to a working capital constraint and require credit to finance a fraction of their wage payments. Finally, the price of government debt is determined by international investors that have access to both government debt and a risk-free asset. Within this framework, I show that the introduction of domestic debt has important positive and normative implications.

My main contributions are three. First, while standard sovereign default models (i.e. Arellano, 2008, Aguiar and Gopinath, 2006) assume exogenous output costs upon default, the study of domestic debt allows me to illustrate an endogenous mechanism linking sovereign defaults and output contractions through the credit market, which is consistent with the empirics. In this mechanism, sovereign defaults weaken investors' balance sheets causing a

\footnotetext{
${ }^{1}$ Throughout the paper I use interchangeably the terms "domestic debt" and "internal debt" to refer to domestic holdings of government debt.
} 
contraction of credit and a fall in output. The output contraction strengthens with exposure to domestic debt. ${ }^{2}$ Consequently, domestic debt reduces government incentives to default, making government debt more sustainable. Large domestic holdings of government debt are associated with low default risk and high debt to GDP ratios.

Second, I calibrate the model to Argentina. Quantitative models of sovereign default have difficulties in matching simultaneously the high default rates and the high debt-to-GDP ratios observed in the data. When simulated default rates are realistically high, the simulated debt-to-GDP ratios are excessively low and vice versa. The disciplinary role of domestic debt reduces the tension between the size of government debt and the incidence of defaults and improves the quantitative performance of sovereign default models.

Third, the inclusion of domestic debt leads to interesting normative implications. I underline the crucial role of debt composition in determining the default risk and investigate whether markets can autonomously achieve the efficient composition of debt. I find that whenever domestic investors take government debt prices as given, the competitive equilibrium is not efficient. Domestic investors consume too much and lend too little to the government. Suboptimal debt composition also affects the management of aggregate government debt, which is also found to be inefficiently low. Efficiency can be restored by introducing a Pigouvian subsidy that incentivizes domestic purchases of government bonds.

My work is closely related to Arellano (2008) and Aguiar and Gopinath (2006), which build on the seminal work of Eaton and Gersovitz (1981) and propose models of sovereign default that match key moments in the data. In this paper, I also develop a theoretical model of sovereign default that is employed to match the evolution of the Argentinean economy from 1980 to 2001. My paper also relates to the literature on the interplay of sovereign defaults, financial intermediaries, and the credit market. Gennaioli et al. (2014), Bolton and Jeanne (2011), Brutti (2011), Bocola (2015), and Sosa-Padilla (2014) develop quantitative models of sovereign default studying the relation between sovereign defaults and the banking sector. ${ }^{3}$

\footnotetext{
${ }^{2}$ Theoretical sovereign default models have typically associated output losses to exogenous external forces (i.e., Arellano, 2008, and Mendoza and Yue, 2012). In retaliation against defaults, lenders exclude countries from international financial markets and international trade causing output contraction. This view, however, has been challenged by several empirical works (i.e., DePaoli et al., 2009; Sandleris, 2012; and Borensztein and Panizza, 2009), showing that output contraction around defaults is actually explained by the contraction of domestic credit.

${ }^{3}$ Gennaioli et al. (2014) propose a model relating the size of output contraction to the development of the domestic financial sector. More developed financial sectors sustain higher quantities of government debt. As sovereign defaults weaken the balance sheet of banks, greater exposure reduces the incentives to default. Similarly, Brutti (2011) proposes a stylized model in which government debt is used to store liquidity and sovereign default causes a liquidity shortage. Finally, Bolton and Jeanne (2011), and Sosa-Padilla (2014)
} 
My paper builds on this literature, assigning a crucial role to the interaction between the sovereign debt market and the credit market. Specifically, in my model, sovereign defaults cause a contraction of the credit supply and ultimately a contraction of output. My paper departs from this literature as it studies both domestic and external debt within a single framework and investigates the normative implications of such extension. Firstly, my paper highlights the importance of debt composition to determine the default risk. Secondly, I claim that government intervention is needed to achieve the efficient equilibrium.

My paper also relates to the work of Broner et al. (2010), which argues that the presence of complete secondary markets for government debt, paired with the ability of the government to distinguish between domestic and foreign lenders, can rationalize the existence of government debt even in the absence of default costs. ${ }^{4}$ In my work, I also emphasize the crucial role of domestic debt determining default risk and default costs. However, my paper departs from Broner et al. (2010) in that it does not aim to rationalize the existence of government debt but rather aims to study the quantitative and normative implications of the existence of domestic debt.

Finally, my paper also relates to the literature on externalities in small open economies. Mendoza and Bianchi (2010) show that sudden stop episodes are explained by excessive borrowings. Agents fail to internalize the consequences of their own actions on borrowing terms and borrow too much. In this paper, I show that a similar mechanism applies to the sovereign debt market, but with different implications. Whenever domestic investors are too small to internalize the impact of their purchases on borrowing terms, domestic investors consume too much and lend too little to the government. Governments, thus, borrow too little from abroad and default too often. Efficiency can be restored by subsidizing domestic purchases of government bonds. ${ }^{5}$

The rest of the paper is organized as follows. Section 2 presents some stylized facts about the relationship between sovereign defaults and domestic debt. Section 3 introduces the theoretical model. Section 4 formally defines the competitive equilibrium for the model economy. Section 5 defines the constraint efficient equilibrium and discusses the existence of a pecuniary externality in the economy. Section 6 explains the calibration of the model.

also develop models that link default costs to bank holdings of government debt.

${ }^{4}$ The argument is very intuitive. Efficient secondary markets can be used to transfer government bond holdings from foreign lenders to domestic ones if the government decides to default. If this is the case, an altruistic government never defaults and the existence of government debt is justified.

${ }^{5} \mathrm{Na}$ et al. (2015) also highlight the existence of a pecuniary externality in a model with defaultable debt. In their model, however, debt is issued by domestic households and purchased by external agents. As a result, the direction of the externality is the opposite. Domestic investors issue too much debt. 
Section 7 investigates dynamics in the competitive equilibrium. Section 8 discusses the normative implications of the introduction of domestic debt. Section 9 concludes the paper.

\section{Stylized Facts}

The sovereign default literature has concentrated on external debt dynamics, while very little has been said about domestic holdings of government debt. Reinhart and Rogoff (2008) review a large sample of default episodes and conclude that there is a "forgotten history of domestic debt". Domestic debt has been greatly overlooked despite the existence of vast empirical evidence suggesting that domestic debt dynamics are important to assess the sustainability of public balances. In this section, I present some stylized facts confirming the importance of domestic debt.

Data about domestic holdings of government debt were gathered from a number of different data sources. Most of the data were collected from the Quarterly Public Sector Debt database (QPSD) compiled by the World Bank. As some countries with interesting domestic debt dynamics are not surveyed (i.e., Argentina and Japan) in the QPSD, I complemented QSPD data with data from the International Debt Statistics database (IDS), also compiled by the World Bank, and with data from the Bruegel Sovereign Bond Dataset (BSBD). ${ }^{6}$

\section{Domestic Debt Size}

Figure 1 describes the composition of debt at the end of 2011 for a sample of emerging and developed economies. For all the countries in the sample, the share of domestic-to-total debt is large. Even for small open economies like Austria and Ireland, the domestic-to-total debt ratio is above 0.25 . The median internal-to-total debt ratio is roughly 0.6 , meaning that internal debt is actually the largest component of public debt.

\footnotetext{
${ }^{6}$ IDS contains yearly data for external public debt. Domestic debt is estimated as the difference between total debt and external debt. Total government debt figures are taken from Reinhart and Rogoff's "This time is different" website. Finally, BSBD collects quarterly data about public debt and its composition for the major European economies.
} 
Figure 1. Domestic to Total Debt Ratio

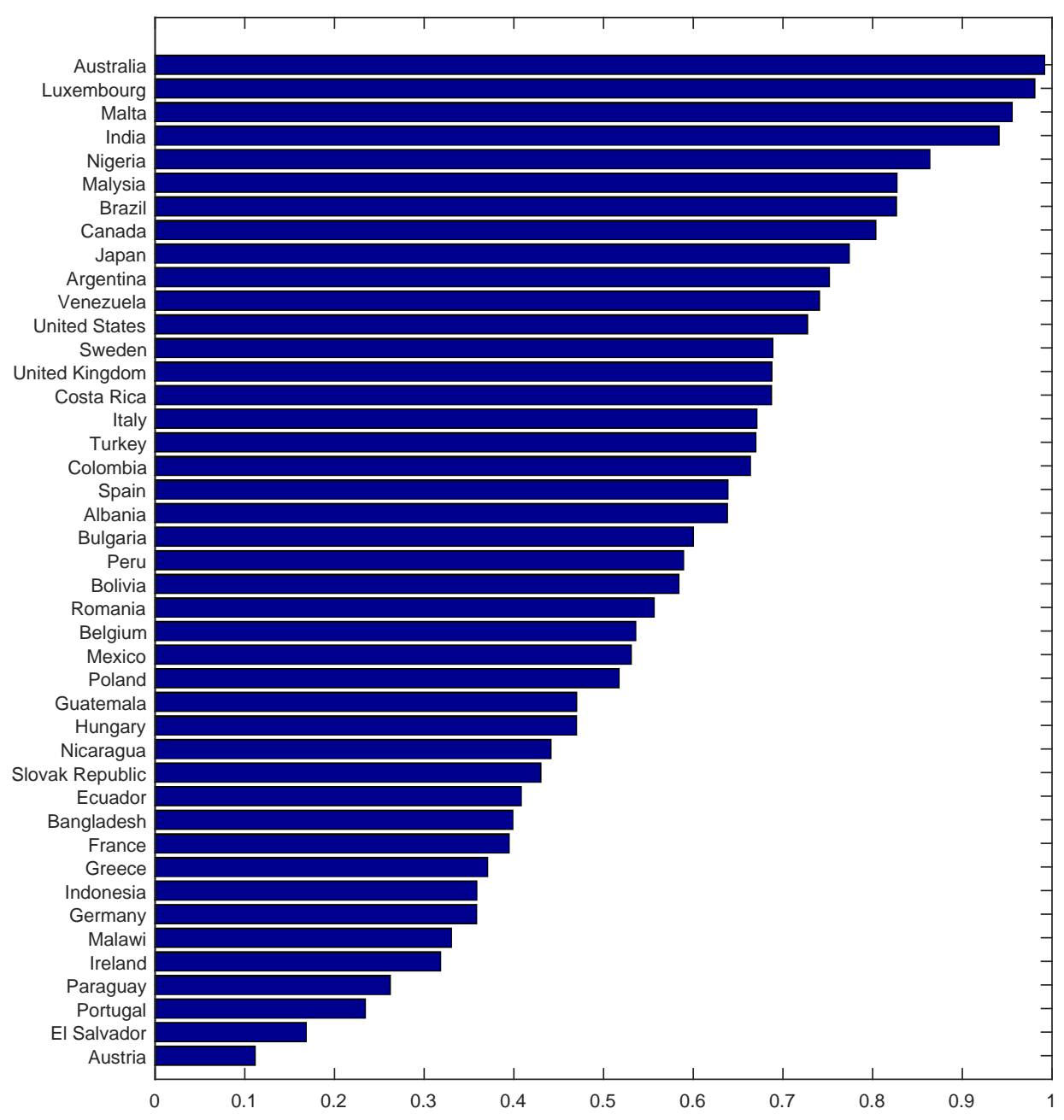

Figure 1 displays the domestic to total debt ratio for a sample of 43 countries measured in the last quarter of 2011.

\section{Default Incidence}

According to the conventional view, domestic debt is senior to external debt and episodes of outright defaults on domestic debt should be rare. Empirical evidence, however, does not 
support this view. Table 1 groups default episodes into different categories according to the jurisdiction of the debt titles involved. ${ }^{7}$ About $55 \%$ of the default episodes between 1990 and 205 were non-discriminatory defaults on both domestic and external holdings of government debt. The case of Argentina is emblematic. Argentina defaulted three times since 1980-once on domestic debt in 1989 and twice on both external and domestic debt in 1982 and 2001.

Table 1. Incidence of Sovereign Defaults

\begin{tabular}{cccc}
\hline \hline Time & Non-Selective & Domestic & External \\
\hline \hline $1990-2005$ & $55 \%$ & $18 \%$ & $27 \%$ \\
$1980-2005$ & $25 \%$ & $23 \%$ & $52 \%$ \\
\hline \hline
\end{tabular}

Table 1 displays the incidence of sovereign default episodes. Episodes are grouped according to the jurisdiction of the debt titles involved in the default. Non-selective defaults involve debt titles that were issued both in the domestic and in a foreign jurisdiction.

\section{Defaults and Output Contraction}

Countries typically incur output losses around default episodes. Table 2 shows the average evolution of normalized output around default in a sample of 49 default episodes. Default episodes are classified in two groups: "purely external" defaults only involve the external component of debt, and "also domestic" default episodes involve domestic holdings of government debt either because they are non-discriminatory defaults or because they are purely domestic defaults. Output contracts more around default episodes that also involve domestic holdings of government debt. Pure external default episodes are associated with a $1 \%$ contraction in output, while defaults that also involve the domestic component are associated with a contraction of output of more than $12 \%$. The t-test for the means confirms that the output contraction is statistically different in the two groups. Reinhart and Rogoff (2008) also check for the differential response of output to domestic and external defaults and confirm that output fluctuation around default is smaller when default is limited to external debt.

\footnotetext{
${ }^{7}$ The complete list of default episodes is reported in Table 9 in the Appendix.
} 
Table 2. Output Dynamics around Default

\begin{tabular}{cccc}
\hline \hline \multicolumn{4}{c}{ Normalized Average Output Levels } \\
Time & Purely External & Also Domestic & T-test \\
\hline \hline $\mathrm{t}-3$ & 104 & 93 & 1.27 \\
$\mathrm{t}-2$ & 107 & 99 & 1.04 \\
$\mathrm{t}-1$ & 100 & 100 & 0.00 \\
$\mathrm{t}$ & 99 & 87 & $2.05^{* *}$ \\
$\mathrm{t}+1$ & 106 & 96 & 1.28 \\
$\mathrm{t}+2$ & 116 & 108 & 0.75 \\
$\mathrm{t}+3$ & 123 & 120 & 0.21 \\
\hline \hline
\end{tabular}

Table 2 describes the evolution of output around default episodes. The second and third columns display the evolution of output levels distinguishing between purely external defaults (30 episodes) and defaults that also involve domestic holdings of government debt (19 episodes). Figures are obtained averaging across default episodes and normalizing output levels at $t-1$. The last column presents the t-statistics for the differences between the two series. $\left(^{*}\right)$ indicates significance at the $10 \%$ confidence level. $(* *)$ indicates significance at the $5 \%$ confidence level.

\section{Defaults and Credit Contraction}

Understanding why defaults on domestic debt are associated with greater output losses requires a deep understanding of the channels relating the sovereign bond market to the real economy. The theoretical literature has typically related output contraction to external factors such as the exclusion from trade and financial markets. However, this view has found little empirical support. Empirical studies (e.g., Sandleris, 2012) have shown that the reduction of trade volumes observed in the aftermath of sovereign default episodes is a consequence, not a cause, of output contraction. Similarly, the length of the exclusion time from financial markets is too short to explain the contraction of output. ${ }^{8}$

Recent developments in the empirical literature have underlined the importance of internal factors in determining the size of output contraction around sovereign default episodes (DePaoli et al., 2009). In particular, the contraction of internal (Albertazzi et al., 2014) and external (Arteta and Hale, 2008) credit appears to play a key role. Gennaioli et al. (2014)

\footnotetext{
${ }^{8}$ The median exclusion length has dropped from four years in the 1980s to two years in the 1990s. (Gelos et al., 2011)
} 
Table 3. Credit Supply around Default

\begin{tabular}{cccc}
\hline \hline & \multicolumn{2}{c}{ Normalized Average Credit to GDP Ratio } & \\
Time & Purely External & Also Domestic & T-test \\
\hline \hline t-3 & 93 & 92 & 0.20 \\
t-2 & 97 & 97 & 0.15 \\
t-1 & 100 & 100 & 0.00 \\
t & 101 & 92 & $1.78^{*}$ \\
t+1 & 99 & 81 & $2.10^{* *}$ \\
t +2 & 96 & 82 & 1.46 \\
t +3 & 90 & 93 & 0.29 \\
\hline \hline
\end{tabular}

Table 3 describes the evolution of credit around default episodes. The second and third columns display the evolution of normalized private credit-to-GDP ratios distinguishing between purely external defaults (21 episodes) and defaults that also involve domestic holdings of government debt (16 episodes). Numbers are obtained by averaging across default episodes. The last column presents the t-statistics for the differences between the two series. $(*)$ indicates significance at the $10 \%$ confidence level. (**) indicates significance at the $5 \%$ confidence level.

find that financial intermediaries reduce credit supply around default in a way that is proportional to their holdings of government debt. Intuitively, the greater the exposure toward government debt titles, the bigger the losses upon default. This finding is also confirmed by Sandleris (2012).

Table 3 displays the average evolution of the credit-to-GDP ratio around default episodes in a sample of 37 default episodes. ${ }^{9}$ Credit is measured as the new loans supplied by financial intermediaries to the private sector. ${ }^{10}$ Credit contracts $19 \%$ in the two years that follow a domestic default episode and only $1 \%$ in the aftermath of an external default. The t-test for the means confirms that the contraction of the credit market is statistically different in the two groups.

\footnotetext{
${ }^{9}$ Data about the credit market are taken from the Financial Structure Dataset (FSD) created by Beck et al. (2009). A complete list of the episodes surveyed is contained in Table 9.

${ }^{10}$ Data about other segments of the credit market - such as market for bonds - are scarce and incomplete. A few countries (i.e. Argentina) report information about these other segments. In all these countries intermediated credit is by far the biggest segment of the credit market and drives the behavior of the credit market as a whole.
} 


\section{Model}

In this section, I develop a dynamic stochastic general equilibrium model with endogenous default risk that includes both domestic and external debt. The economy is composed of four sectors: firms, domestic households/investors, external investors and the government.

\subsection{Firms}

Output $y$ is produced by perfectly competitive firms employing labor $N$ as the only input factor. Firms are subject to a productivity shock $z$ and the production function is linear in labor: ${ }^{11}$

$$
y=z N
$$

Firms are subject to a working capital constraint, as in Mendoza and Yue (2012), and need to pay a fraction $\gamma$ of the labor costs before output is realized. Anticipated wage payments are financed with intra-temporal loans $l$ that are supplied by domestic investors against the payment of an interest rate $r^{L}$. Firms' demand for credit $l$ is determined by the working capital constraint:

$$
l=\gamma w N
$$

where $w$ is the wage rate. Labor demand $N$ is chosen to maximize profits:

$$
\max _{N}\left\{z N-w N-r^{L} \gamma w N\right\}
$$

The first order condition associated with the maximization problem of the firm is

$$
N: w=\frac{z}{1+\gamma r^{L}}
$$

Equation (4) relates wages to the marginal product of labor and to the conditions prevailing in the credit market. Higher loan rates $r^{L}$ reduce the wage rates. Multiplying both sides of equation (4) by $\gamma N$, I obtain the loan demand function that relates the credit demand $l$ to

\footnotetext{
${ }^{11}$ The linearity of the production function ensures that the competitive equilibrium and the constraint efficient equilibrium - defined in Sections 4 and 5 - coincide for a given price of government debt.
} 
the interest rate on loans $r^{L}$ :

$$
l=\frac{z \gamma N}{1+\gamma r^{L}}
$$

\subsection{Households}

The economy is populated by a continuum $i$ of households with mass one. Households value consumption $c$ and dislike labor $N$ according to the flow utility $U(c, N)$. Preferences are GHH:

$$
U(c, N)={\frac{\left(c-\frac{1}{\omega} N^{\omega}\right)}{1-\sigma}}^{(1-\sigma)} .
$$

The problem for the household is that of making contingent plans for consumption $c$, labor supply $N$, individual domestic bond holdings $b^{\prime H}$, and fresh equity issuance $\mathcal{S}$ so as to maximize its lifetime utility. Households supply labor to firms and invest savings either by purchasing government bonds or by supplying credit to firms. To ease the exposition, I discuss separately the labor supply decision, which I name the worker's problem, and the saving and investment decision, which I name the investor's problem.

\section{Worker's Problem}

Workers choose labor supply $N$ and consumption levels $c$ to maximize the utility of the households. Each period is divided into two interim times, morning and afternoon. In the morning, a fraction $\gamma$ of the wage payments is paid to workers before output is realized. Workers also receive a lump-sum transfer $T$ from the government and contribute fresh equity $\mathcal{S}$ to investors. ${ }^{12}$ Workers budget constraint in the morning is

$$
\mathcal{S}=\gamma w N+T
$$

In the afternoon, workers receive investors' gross profits $\pi^{I}$ and the outstanding wage payments $(1-\gamma) w N$. Resources are used to finance household consumption $c$. The budget

\footnotetext{
${ }^{12}$ Taxation is introduced in a lump-sum fashion for the sake of simplicity. Distortionary taxes on labor would reduce the sustainability of government debt and increase the default frequency, but they would not alter the qualitative and normative implications of the model.
} 
constraint in the afternoon is

$$
c=(1-\gamma) w N+\pi^{I}
$$

The maximization problem of the worker is

$$
\max _{c, N}{\frac{\left(c-\frac{1}{\omega} N^{\omega}\right)}{1-\sigma}}^{(1-\sigma)}
$$

subject to

$$
c=w N+T+\pi^{I}-\mathcal{S} .
$$

The budget constraint in equation (10) is obtained by combining equations (7) and (8). The last two terms on the right-hand side of the budget constraint identify the profits from investment net of equity contributions. Net profits from investment are taken as given by the workers as they are determined in the investors' problem. The objective function (9) does not include the continuation value, as the labor supply choice is strictly intra-temporal. The first-order condition associated with the labor supply decision is standard:

$$
N: N^{\omega-1}=w
$$

Multiplying both sides of equation (11) by $\gamma N$ and rearranging the terms, I can express labor as a function of the credit supply $l$ :

$$
N=\left(\frac{l}{\gamma}\right)^{\frac{1}{\omega}} .
$$

Equations (4), (5), and (12) jointly determine equilibrium prices and quantities in the labor market as a function of the interest rate $r^{L}$ prevailing in the credit market. Ceteris paribus, higher interest rates are associated with lower wages and a lower supply of labor in equilibrium.

\section{Investors' Problem}

Investors choose the optimal investment strategy on behalf of the households. Investors have access to two different markets: the market for government bonds $b^{\prime H}$ and the market for 
credit to firms $l$. Investors behave competitively in the market for bonds while they enjoy a monopoly in the market for loans. ${ }^{13}$ Monopolistic investors internalize the impact of their choices on credit demand. ${ }^{14}$ The problem of the investors is divided into two interim periods, morning and afternoon. Each period is analyzed separately.

In the morning, investors receive liquidity from maturing bonds $b^{H}$. Liquidity is employed to produce loans $l$ and purchase government bonds $b^{\prime H}$ at price $q$. Investors may also issue fresh equity $\mathcal{S}$ to expand the resources available for investment. Investors' resource constraint in the morning is

$$
l+q b^{\prime H}=b^{H}+\mathcal{S} .
$$

Using the balance sheet identity, investors' net worth $e$ after loans have been extended is defined as

$$
e \equiv l+q b^{\prime H}
$$

Combining equations (13) and (14), I obtain the net worth equation:

$$
e=b^{H}+\mathcal{S}
$$

Net worth is the sum of domestic holdings of government debt $b^{H}$ and the fresh equity $\mathcal{S}$.

Following a large body of the literature (i.e., D'Erasmo et al., 2014; and Guerrieri et al., 2013), it is assumed that investors are subject to a capital constraint. The capital constraint introduces a link between the supply of credit and the value of investors' net worth:

$$
e \geq(1-\psi) l
$$

Investors' net worth needs to be larger than the risk-weighted value of investors' assets. $(1-\psi)$ is the risk weight assigned to loans to the private sector. Financial regulations assign no risk to domestic government debt issued in domestic currency. This preferential treatment is captured in equation (16) by the absence of domestic debt on the right-hand

\footnotetext{
${ }^{13}$ This assumption is justified by the high concentration levels observed in the market for intermediated credit. Monopolistic competition is also introduced to ensure that the supply of credit in the competitive equilibrium and in the constrained efficient equilibrium defined in Sections 4 and 5 , respectively, coincide for a given price of government debt.

${ }^{14}$ Credit demand is jointly defined by equations (2), (5) and (12). Equations (5), and (12) define equilibrium quantities and prices in the labor market. Equation (2) relates credit demand and wage payments in the economy.
} 
side of the equation. Combining equations (15) and (16) I obtain

$$
l \leq \frac{b^{H}+\mathcal{S}}{(1-\psi)}
$$

Constraint (17) is binding in the parameter space defined by the calibration in Section 6, which is why in the remainder of the analysis I assume that the collateral constraint is always binding. Equations (15) and (17) jointly describe the consequences of sovereign defaults on investors' balance sheets. Upon default, investors' net worth falls and their ability to supply credit to the economy is reduced. This mechanism endogenously explains output contraction upon default.

In this paper, I rely on the assumption that investment opportunities are limited to government bonds and private credit. Expanding the set of investment opportunities to include foreign government bonds would not change the functioning of the mechanism highlighted above as long as domestic investors hold some debt when the government decides to default. The amplitude of investors' balance sheet contraction and the output costs associated with a default, instead, crucially depend on the relative size of government debt in the portfolio of domestic investors. Stylized facts presented in Section 2 suggest that government bond holdings are a large fraction of investors' assets. In the calibration exercise, I choose parameter values to reproduce the same share of domestic government bonds in the investment portfolio of financial intermediaries that is observed in the empirics.

In the afternoon, investors receive gross interest payments $\left(1+r^{L}\right)$ from firms. Following the tradition in the corporate finance literature, it is assumed that equity issuance $\mathcal{S}$ entails some additional costs that are paid in the afternoon. These costs are summarized by the quadratic cost function $\Phi(S)=I_{\mathcal{S} \geq 0}\left[\phi_{0} \mathcal{S}+\phi_{1} \mathcal{S}^{2}\right]$, as in Hennessy and Whited (2005). ${ }^{15}$ Income from investment $\pi^{I}$ gross of equity contribution is

$$
\pi^{I}=\left(1+r^{L}\right) l-\Phi(\mathcal{S})
$$

Let $B^{H} \equiv \int_{0}^{1} b^{H} d i$ be the aggregate level of domestic bond holdings and $\hat{B}^{\prime H}=H\left(z, B, B^{H}\right)$ the forecasting rule adopted by the generic investor to predict the evolution of aggregate domestic bond holdings. ${ }^{16}$ The maximization problem of each investor on behalf of the

\footnotetext{
${ }^{15}$ The calibration of the two parameters $\phi_{0}$ and $\phi_{1}$ is crucial. If bank recapitalization is costless, households can always compensate banks for the losses caused by a default. Parameters are therefore calibrated to replicate empirical moments.

${ }^{16}$ Government debt price depends on the evolution of aggregate domestic debt. As such, it is necessary to define a forecasting rule that individual investors adopt to update their belief about the evolution of
} 
household is

$$
\begin{array}{r}
\max _{b^{\prime H}, \mathcal{S}} V^{H}\left(z, B, B^{H}, b^{H}\right)={\frac{\left(c-\frac{1}{\omega} N^{\omega}\right)}{1-\sigma}}^{(1-\sigma)}+\beta E\left(1-d e f^{\prime}\right) V^{\prime H}\left(z^{\prime}, B^{\prime}, B^{\prime H}, b^{\prime H} \mid z\right) \\
+\beta E d e f^{\prime} V^{\prime H}\left(z^{\prime}, 0,0,0 \mid z\right),
\end{array}
$$

Subject to:

$$
\begin{gathered}
c=w N+T+\pi^{I}-\mathcal{S}, \\
\pi^{I}=\left(1+r^{L}\right) l-\Phi(\mathcal{S}) ; \\
l+q b^{\prime H}=b^{H}+\mathcal{S}, \\
l=\frac{b^{H}+\mathcal{S}}{(1-\psi)} \\
l=\gamma w N, \\
r^{L}=\frac{z N}{l}-\frac{1}{\gamma}, \\
N=\left(\frac{l}{\gamma}\right)^{\frac{1}{\omega}} \\
\hat{B}^{\prime H}=H\left(z, B, B^{H}\right) .
\end{gathered}
$$

Equation (25) defines the interest rate on loans that is obtained by rearranging the loan demand function in equation (5). Equations (24), (25) and (26) jointly determine equilibrium conditions in the labor and credit markets and are derived by solving the maximization aggregate quantities of domestic bond holdings. 
problem of the workers and of the firms. They are included in the set of the constraints faced by the domestic investors because of the monopolistic competition in the credit market. Combining equations (20), (21), (22), (24), and (25), the budget constraint of the household can be written more succinctly as

$$
c=z N+b^{H}-q b^{\prime H}-\Phi(\mathcal{S})+T
$$

Households' consumption and the cost of producing equity are financed with production, external borrowings, and government transfers. The first-order conditions associated with the investors' problem are

$$
\begin{gathered}
b^{\prime H}: q=\beta E \frac{\left(c^{\prime}-\frac{N^{\prime \omega}}{\omega}\right)^{-\sigma}}{\left(c-\frac{N^{\omega}}{\omega}\right)^{-\sigma}}\left[1+z^{\prime} \frac{\partial N^{\prime}}{\partial b^{\prime H}}\right] \\
\mathcal{S}: z \frac{\partial N}{\partial \mathcal{S}}=\frac{\partial \Phi(\mathcal{S})}{\partial \mathcal{S}}
\end{gathered}
$$

Equation (29) states that in equilibrium, the marginal cost of purchasing an additional unit of government debt equals the expected marginal utility derived from an additional unit of consumption and an additional unit of production. Equation (30) states that the marginal cost of issuing an additional unit of equity must equate the marginal increase in current level of output in equilibrium.

\subsection{International Investors}

International investors are risk-neutral agents with deep pockets. They have access to two different inter-temporal investment opportunities. The first investment opportunity is a riskfree asset that pays the risk-free interest rate $r^{f}$ in every possible contingency. The second investment opportunity is the risky government bond that pays 0 when the government defaults and 1 otherwise. As international investors are risk-neutral, the price $q$ of government bonds is derived by arbitrage and is equal to

$$
q\left(z, B^{\prime}, B^{\prime H}\right)=\frac{1-P\left(d e f^{\prime} \mid z\right)}{1+r^{f}} .
$$

The price depends on the probability of default and on the risk-free rate. The higher the probability of default, the lower the price of government debt. Similarly, the higher the 
risk-free rate, the lower the price of government debt. The probability of default depends on the realization of three states: productivity $z$, government debt levels $B^{\prime}$, and domestic debt levels $B^{\prime H}$. Low productivity and high government debt levels make debt servicing more expensive and increase the risk of default. Larger domestic holdings of government debt, instead, reduce the risk of default, as they are associated with higher output costs upon default.

Equation (31) defines the market-clearing price of government bonds for international riskneutral investors. Under the assumption that the government cannot operate selective defaults, equation (31) defines the price for both the domestic and external components of government debt.

\subsection{Government}

The optimal government policy is defined by the government borrowing rule $B^{\prime *}$ and the default decision $d e f^{*}$ that maximize the welfare of the economy. The government is subject to the following budget constraint:

$$
T+B=q B^{\prime}
$$

Transfers and bond payments are financed by issuing new government debt. Combining equations (28) and (32), I obtain the resource constraint of the economy:

$$
c+\Phi(\mathcal{S})=z N+q\left(B^{\prime}-B^{\prime H}\right)-\left(B-B^{H}\right)
$$

Households consumption and the cost of issuing fresh equity are financed with output and net external borrowings. In the non-default scenario, the optimal government borrowing rule $B^{\prime *}$ maximizes the welfare of the household subject to the equilibrium conditions in the labor and credit markets derived in the maximization problems of firms and households. The government solves the following maximization problem

$$
W^{n d}=\max _{B^{\prime}} V^{n d}\left(z, B, B^{H}\right)
$$

subject to:

$$
V^{n d}\left(z, B, B^{H}\right)={\frac{\left(c-\frac{1}{\omega} N^{\omega}\right)}{1-\sigma}}^{(1-\sigma)}+\beta E V^{n d}\left(z^{\prime}, B^{\prime}, B^{\prime H} \mid z\right)
$$




$$
\begin{gathered}
c+q\left(B^{\prime H}-B^{\prime}\right)-\left(B^{H}-B\right)=z N-\Phi(\mathcal{S}), \\
N=\left(\frac{B^{H}+\mathcal{S}}{\gamma(1-\psi)}\right)^{\frac{1}{\omega}}, \\
q\left(z, B^{\prime}, B^{\prime H}\right)=\frac{1-P\left(d e f^{\prime} \mid z\right)}{1+r^{f}} .
\end{gathered}
$$

Equation (36) describes the equilibrium conditions in the labor market and is obtained from equations (23) and (26). The first-order condition associated with the maximization problem of the government is

$$
B^{\prime}: q-\frac{\partial q}{\partial B^{\prime}}\left(B^{\prime}-B^{\prime H}\right)=\beta E\left[\frac{\left(c^{\prime}-\frac{N^{\prime \omega}}{\omega}\right)^{-\sigma}}{\left(c-\frac{N^{\omega}}{\omega}\right)^{-\sigma}}\right] .
$$

The marginal benefit of issuing an additional unit of government debt is the price $q$ at which the government sells its bonds. The marginal cost of issuing bonds is the worsening of the borrowing terms times the size of external debt and the expected decrease of future consumption. In equilibrium, the marginal cost and the marginal benefit of issuing bonds equate.

Upon default, the government is excluded from financial markets. However, it can be readmitted with an exogenous probability $\lambda$. The welfare of the economy in the default scenario is expressed by

$$
W^{d}=V^{d}(z, 0,0)
$$

Subject to:

$$
\begin{gathered}
V^{d}(z, 0,0)={\frac{\left(c-\frac{1}{\omega} N^{\omega}\right)}{1-\sigma}}^{(1-\sigma)}+\beta E\left\{(1-\lambda) V^{d}\left(z^{\prime}, 0,0 \mid z\right)+\lambda V^{\prime n d}\left(z^{\prime}, 0,0 \mid z\right)\right\} \\
N=\left(\frac{0+\mathcal{S}}{\gamma(1-\psi)}\right)^{\frac{1}{\omega}}, \\
c=z N-\Phi(\mathcal{S}) .
\end{gathered}
$$


The government takes the default decision comparing households' welfare in the default scenario and in the non-default scenario:

$$
W\left(z, B, B^{H}\right)=\max _{\operatorname{def} \in\{0,1\}}(1-\operatorname{def}) W^{n d}+\operatorname{def} W^{d}
$$

The government decides to default when the welfare of the household in the default scenario is higher than in the non-default scenario.

\section{Competitive Equilibrium}

The recursive competitive equilibrium is derived in three steps. First, I define the optimal saving and investment policy of the household. Second, I turn to the definition of the optimal government policy. Finally, I characterize the recursive competitive equilibrium. ${ }^{17}$

Saving and Investment Policy: The optimal individual saving and investment policy is a set of prices $\left\{w^{C E *}, r^{L, C E *}\right\}$ and quantities $\left\{b^{\prime H, C E *}\right\}$ with associated consumption, labor, equity, credit, and production plans $\left\{c^{C E *}, N^{C E *}, \mathcal{S}^{C E *}, l^{C E *}, y^{C E *}\right\}$ such that for a given government policy $\{T, d e f\}$, for a given sovereign debt price $q$, and for a given forecasting rule $B^{\prime H}=H\left(z, B, B^{H}\right)$, prices and quantities solve the maximization problems of firms and households described in Section 3.1 and Section 3.2 and the individual and aggregate quantities coincide: $B^{\prime H, C E *}=\int_{0}^{1} b^{H, C E *} d i=b^{\prime H, C E *}$ and $L^{C E *}=\int_{0}^{1} l^{C E *} d i=l^{C E *}$.

Optimal Government Policy: The optimal government policy is defined by the government borrowing rule $B^{\prime C E *}$ and the default decision $d e f^{C E *}$ that maximize the welfare of the economy given the equilibrium conditions for the labor and the credit market associated with the maximization problems of firms and households and given the asset pricing equation (31). The optimal government policy solves the maximization problem presented in Section 3.4 .

\footnotetext{
${ }^{17}$ In this model investors behave competitively in the labor markets and in the bonds market, but they behave monopolistically in the credit market. Hence, the notion of "competitive" equilibrium is not entirely correct. The equilibrium in the model economy would be more correctly defined as a "competitive equilibrium with monopolistic competition in credit market". To maintain the terminology as coincisely as possible, I refer to the equilbrium as "competitive" with a small abuse of terminology.
} 
Recursive Competitive Equilibrium: A recursive competitive equilibrium is a government borrowing and default rule $\left\{B^{\prime C E *}\right.$, def $\left.f^{C E *}\right\}$ and an individual saving rule $\left\{b^{\prime H, C E *}\right\}$ with associated consumption, labor, equity, credit, and production plans $\left\{c^{C E *}, N^{C E *}, \mathcal{S}^{C E *}\right.$, $\left.l^{C E *}, y^{C E *}\right\}$, equilibrium prices $\left\{w^{C E *}, r^{L, C E *}\right\}$, and equilibrium asset pricing equation $q^{C E}$ for sovereign bonds such that:

- The saving, consumption, labor, equity, credit, and production plans $\left\{b^{\prime H, C E *}, c^{C E *}, N^{C E *}\right.$, $\left.\mathcal{S}^{C E *}, l^{C E *}, y^{C E *}\right\}$ solve the maximization problem of the households and the representative firms given the optimal government policy $\left\{B^{\prime C E *}\right.$, de $\left.f^{C E *}\right\}$, the price $q^{C E *}$, and aggregate domestic bond holdings $B^{\prime H, C E *}=H\left(z, B, B^{H}\right)$.

- The individual and the aggregate saving decisions coincide: $B^{\prime H, C E *} \equiv \int_{0}^{1} b^{\prime H, C E *} d i=$ $b^{\prime H, C E *}$.

- Individual and aggregate loan supplies coincide: $L^{C E *} \equiv \int_{0}^{1} l^{C E *} d i=l^{C E *}$.

- The borrowing rule $B^{\prime C E *}$ and the default rule $d e f^{C E *}$ solve the government decision problem, given the equilibrium conditions for the labor and the credit markets associated with the maximization problems of firms and households.

- The asset pricing equation for government debt satisfies equation (31): $q^{C E *}=\frac{1-\operatorname{Pr}\left(d e f^{\prime C E *}\right)}{1+r^{f}}$.

- The credit market and the labor market clear at prices $\left\{w^{C E *}, r^{L, C E *}\right\}$.

- The taxation rule $T^{C E *}$ satisfies the government budget constraint (32).

\section{Recursive Constrained Efficient Equilibrium and Pe- cuniary Externality}

The constrained efficient equilibrium is derived by centralizing the problems of the household and the government. In the centralized version of the model, the government takes the saving decision $B^{\prime H, E F *}$ on behalf of the household and simultaneously chooses the size of government debt $B^{\prime E F *}$. The government is still subject to the equilibrium conditions for the labor and credit markets derived in the household's problem and in firms' the problem. The constrained efficient equilibrium is derived in two steps. First, I define the optimal government policy. I then characterize the recursive constrained efficient equilibrium. 
Optimal Government Policy: The optimal government policy is defined by the government borrowing rule $B^{\prime E F *}$, the optimal domestic saving rule $B^{\prime H, E F *}$, and the default decision $d e f^{E F *}$ that jointly maximize the welfare of the economy subject to the resource constraints of the economy and to the equilibrium conditions for the labor and the credit markets derived in the competitive equilibrium.

The optimal borrowing and domestic saving rules in the non-default scenario are the solution to

$$
W^{n d}=\max _{c, B^{\prime}, B^{\prime H}, \mathcal{S}} V^{n d}\left(z, B, B^{H}\right)
$$

subject to

$$
\begin{gathered}
V^{n d}\left(z, B, B^{H},\right)={\frac{\left(c-\frac{1}{\omega} N^{\omega}\right)^{(1-\sigma)}}{1-\sigma}+\beta E V^{n d}\left(z^{\prime}, B^{\prime}, B^{\prime H} \mid z\right),}_{c+q\left(B^{\prime H}-B^{\prime}\right)-\left(B^{H}-B\right)=z N-\Phi(\mathcal{S}),} \\
N=\left(\frac{B^{H}+\mathcal{S}}{\gamma(1-\psi)}\right)^{\frac{1}{\omega}} \\
q\left(z, B^{\prime}, B^{\prime H}\right)=\frac{1-P\left(d e f^{\prime} \mid z\right)}{1+r^{f}} .
\end{gathered}
$$

Equation (44) is the resource constraint of the economy while equation (45) summarizes the equilibrium conditions in the labor market and is obtained by combining equations (23) and (26). The first-order conditions associated with the centralized problem are

$$
\begin{gathered}
B^{\prime H}: q-\frac{\partial q}{\partial B^{\prime H}}\left(B^{\prime}-B^{\prime H}\right)=\beta E \frac{\left(c^{\prime}-\frac{N^{\prime \omega}}{\omega}\right)^{-\sigma}}{\left(c-\frac{N^{\omega}}{\omega}\right)^{-\sigma}}\left[1+z^{\prime} \frac{\partial N^{\prime}}{\partial B^{\prime H}}\right] \\
B^{\prime}: q-\frac{\partial q}{\partial B^{\prime}}\left(B^{\prime}-B^{\prime H}\right)=\beta E\left[\frac{\left(c^{\prime}-\frac{N^{\prime \omega}}{\omega}\right)^{-\sigma}}{\left(c-\frac{N^{\omega}}{\omega}\right)^{-\sigma}}\right]
\end{gathered}
$$




$$
\mathcal{S}: z \frac{\partial N}{\partial \mathcal{S}}=\frac{\partial \Phi(\mathcal{S})}{\partial \mathcal{S}}
$$

Equations (48) and (49) are identical to the corresponding first-order conditions (equations (38) and (30)) derived in the competitive equilibrium. Equation (29), defining the optimal domestic debt level, differs from equation (47) as it contains an extra term on the left-hand side of the equation. As the derivative of the price with respect to domestic bond holdings is positive, domestic debt is smaller in the competitive equilibrium than in the constrained efficient allocation.

Upon default, the government is excluded from financial markets. The government may be re-admitted to financial markets with an exogenous probability $\lambda$. The recursive problem of the government becomes

$$
W^{d}=\max _{c, \mathcal{S}} V^{d}(z, 0,0)
$$

subject to

$$
\begin{gathered}
V^{d}(z, 0,0)=U(c, N)+\beta E\left\{(1-\lambda) V^{d}\left(z^{\prime}, 0,0\right)+\lambda V^{n d}\left(z^{\prime}, B^{\prime}, B^{\prime H}\right)\right\}, \\
c=z N-\Phi(\mathcal{S}), \\
N=\left(\frac{\mathcal{S}}{\gamma(1-\psi)}\right)^{\frac{1}{\omega}} .
\end{gathered}
$$

The associated first order condition is

$$
\mathcal{S}: z \frac{\partial N}{\partial \mathcal{S}}=\frac{\partial \Phi(\mathcal{S})}{\partial \mathcal{S}}
$$

The default decision is taken comparing households' welfare in the default scenario and in the non-default scenario:

$$
W\left(B, z, B^{H}\right)=\max _{\operatorname{def} \in\{0,1\}}(1-\operatorname{def}) W^{n d}+\operatorname{def} W^{d}
$$

The government decides to default when the welfare of the household in the default scenario is higher than in the non-default scenario. 
Constrained Efficient Equilibrium: A recursive constrained efficient equilibrium is a borrowing rule $B^{\prime E F *}$, a domestic saving and investment rule $B^{\prime H, E F *}$, and a default rule $d e f^{E F *}$ with associated household consumption, labor, equity, and production plans $\left\{c^{E F *}\right.$, $\left.N^{E F *}, \mathcal{S}^{E F *}, y^{E F *}\right\}$ and equilibrium pricing equation $q^{E F *}$ for sovereign bonds such that:

- The borrowing rule $B^{\prime E F *}$, the saving and investment rule $B^{\prime H, E F *}$, and default rules $d e f^{E F *}$ with the associated consumption, labor, equity, and production plans $\left\{c^{E F *}\right.$, $\left.N^{E F *}, \mathcal{S}^{E F *}, y^{E F *}\right\}$ solve the centralized problem of the government defined in Section 5 .

- The price function for government debt satisfies equation (31): $q^{E F *}=\frac{1-\operatorname{Pr}\left(\operatorname{def}^{\prime E F *}\right)}{1+r^{f}}$.

- The credit market, the labor market, and the goods market clear.

\subsection{Externality}

Sovereign default models typically assume that the government is a large player that efficiently manages the entire stock of debt. When domestic investors are introduced in the framework, the government loses control of debt composition while retaining control over the size of the debt. The suboptimality of investors' choices emerges comparing the firstorder condition for domestic debt in the competitive equilibrium (equation (29)) and in the constrained efficient equilibrium (equation (47)). In the decentralized equilibrium, domestic investors fail to internalize the impact of domestic purchases of government bonds on government borrowing terms. As a result, domestic holdings of government debt are inefficiently low. The externality is determined by the term

$$
e x t=-\frac{\partial q\left(z, B^{\prime}, B^{\prime H}\right)}{\partial B^{\prime H}}\left(B^{\prime}-B^{\prime H}\right)
$$

The size of the pecuniary externality crucially depends on the sensitivity of government debt price to domestic debt $\frac{\partial q\left(z, B^{\prime}, B^{\prime H}\right)}{\partial B^{\prime H}}$. The externality is large when government borrowing terms are sensitive to the size of domestic debt holdings. The pecuniary externality also affects the management of external debt through the government borrowing terms. Lower domestic holdings of government debt worsen government borrowing terms and reduce the borrowing ability of the government. 


\section{Calibration}

Table 4. Calibration

\begin{tabular}{llcl}
\hline \hline Calibrated Parameter & & Value & Target Statistics/Source \\
\hline \hline Discount factor & $\beta^{B}$ & 0.8 & Standard in default Models \\
Re-entry probability & $\lambda$ & 0.2 & Exclusion length = 1.25 years \\
Autocorrelation of TFP shocks & $\rho$ & 0.96 & Standard RBC \\
Coefficient of relative risk aversion & $\sigma$ & 2 & Standard RBC \\
Variance of TFP shocks & $\sigma_{z}$ & 0.034 & Standard RBC \\
Frisch elasticity & $\omega$ & 1.82 & Standard RBC \\
Risk-free rate & $r^{f}$ & 0.017 & U.S. 5-year bond return \\
Working capital parameter & $\gamma$ & 0.353 & Credit supply/wage bill: 0.353 \\
Capital adequacy ratio & $\psi$ & 0.13 & 0-0.8 risk-weight on loans \\
Cost parameter I & $\phi_{0}$ & -35 & Investors exposure: 0.29 \\
Cost parameter II & $\phi_{1}$ & 116 & Investors exposure var: 0.017 \\
\hline \hline
\end{tabular}

Table 4 reports parameter values that are used for the calibration of the model and the associated target statistics.

The utility function is GHH and the production function is linear in labor. Productivity $z$ follows a standard $\mathrm{AR}(1)$ process: $\log z_{t}=\rho \log z_{t-1}+\epsilon_{t}$, where $\epsilon_{t}$ is a normally distributed productivity shock with variance $\sigma_{z}$. The autocorrelation parameter $\rho$ and the variance of the TFP shocks $\sigma_{z}$ are calibrated using standard values to match the quarterly evolution of productivity.

Table 4 reports parameter values and the corresponding target statistics. The calibration aims to replicate the quarterly behavior of the Argentinean economy from 1980 to 2001. Data sources for the target statistics are listed in Table 8 in the Appendix. The discount factor $\beta$ is chosen to replicate the average default rate of Argentina. Argentina has defaulted on its debt five times since its independence in 1816, implying a default probability of $2.5 \%$, which is my calibration target. ${ }^{18}$ Re-entry probability $\lambda$ is set equal to 0.2 , which is consistent with the mean exclusion length of 1.25 years for Argentina found by Gelos et al. (2011). The risk-

\footnotetext{
${ }^{18}$ While the value of the $\beta$ is rather low for a quarterly calibration, it is in line with the discount rates that are calibrated in a similar fashion by Aguiar and Gopinath (2006), Sosa-Padilla (2014), and Mendoza and Yue (2012).
} 
free rate is calibrated to the average quarterly yield of a five-year US government bond and is set equal to 0.017, as in Arellano (2008). The working capital parameter $\gamma$ is set to match the average private credit-to-wage bill ratio between 1980 and 2001: 35.3\%. ${ }^{19}$ Parameters $\phi_{0}$ and $\phi_{1}$ regulate the size of equity $\mathcal{S}$ and are chosen to match the average exposure rate and its variance. ${ }^{20}$ Investors' exposure is defined as the ratio between domestic debt and the value of financial assets held by financial intermediaries. In this model, investors hold only two types of assets: domestic government bonds and loans to the private sector. According to equation (23), the larger the size of fresh equity $\mathcal{S}$, the smaller the holdings of government debt in the portfolio of domestic investors. Finally, $\psi$ is set equal to 0.13 to mimic financial regulation requirements that prescribe a $0-0.8$ risk weight on loans to the corporate sector. As the choice of 0.13 is somewhat arbitrary, I perform a sensitivity analysis in Section 7.3 to check how a set of key moments are affected by different values of $\psi$.

\section{Dynamics in the Competitive Equilibrium}

\subsection{Endogenous Cost of Defaults and Domestic Debt}

With the introduction of domestic debt output contraction upon default arises endogenously and is determined by the size of domestic debt. The larger the size of domestic debt, the greater the output loss upon default. Domestic debt plays a disciplinary role by reducing the risk of default. Figure 2 describes the default set of the economy as a function of the states. Panel A shows that defaults happen when productivity is low and government debt is high. Panel B shows that the size of the default set is inversely proportional to the size of domestic debt.

The disciplinary role of domestic debt also affects the price function. Panel B of figure 3 describes the relation between sovereign debt price $q\left(z, B, B^{H}\right)$ and domestic holdings of government debt. The price of government debt is increasing in the size of domestic debt, meaning that, ceteris paribus, the risk of default diminishes when domestic debt is large.

\footnotetext{
${ }^{19}$ Credit is measured as the new credit supplied in every period by financial intermediaries. The wage bill is computed as the labor share of the GDP. Data about credit supply and the labor share of GDP are only measured at the yearly frequency. I therefore computed the yearly ratios and assumed that they remain constant over quarters.

${ }^{20}$ Data for domestic exposure are yearly and only available starting from 2000 . because of the scarcity of the data, the mean and the variance for domestic exposure are calculated in the years between 2000 and 2011.
} 
Figure 2. Defaults Set
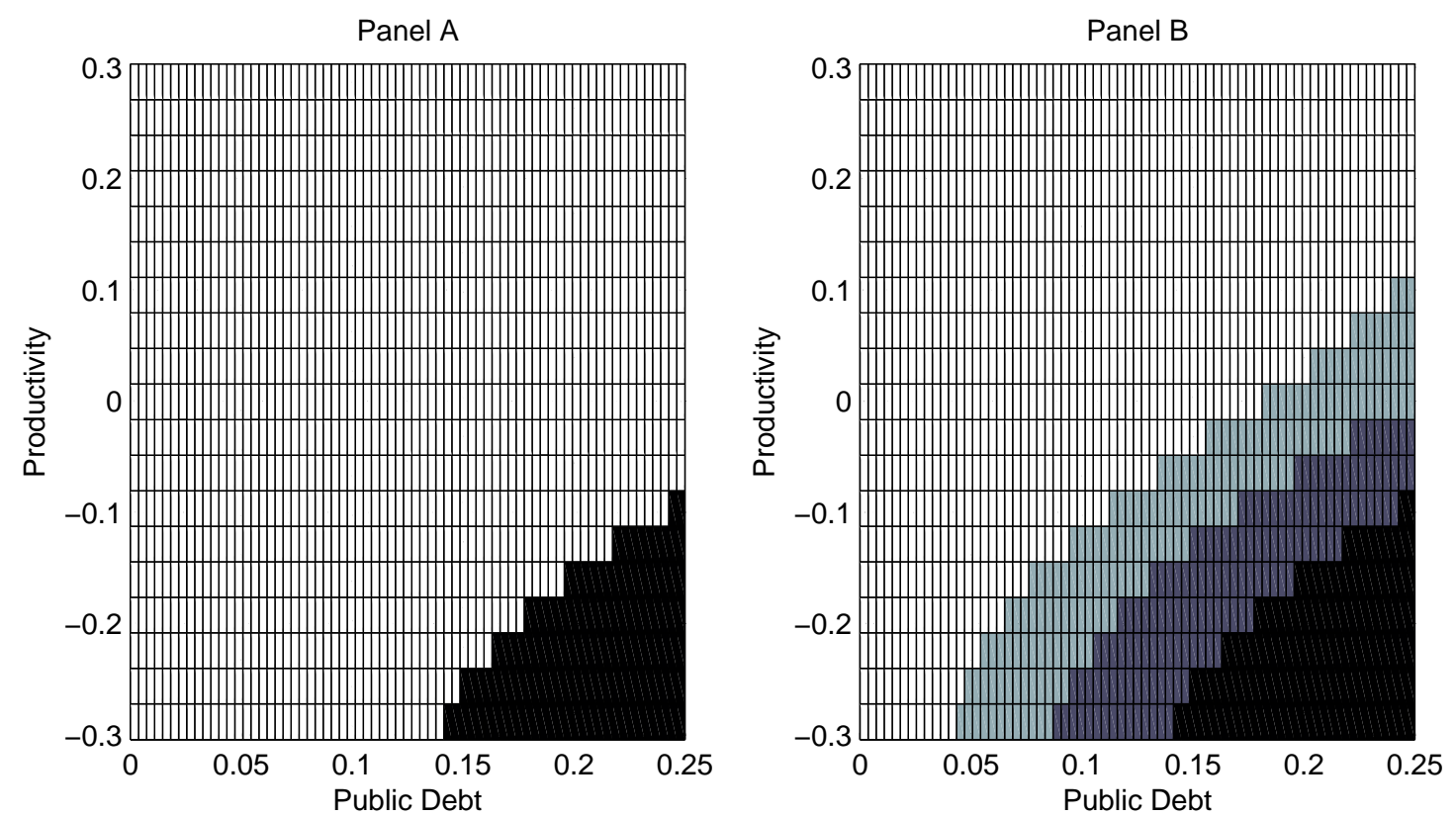

Panel A in Figure 2 draws the default set as a function of total government debt (horizontal axis) and productivity (vertical axis) holding domestic debt constant. The black shaded area highlights the combinations of productivity shocks and debt levels that trigger a default. Panel B draws the default set for three different levels of domestic debt. The default area in black is associated with high levels of domestic debt. The gray and cyan areas are associated with intermediate and low levels of debt, respectively. The default set expands as domestic debt becomes smaller.

\subsection{Business Cycle Moments}

The model is calibrated to reproduce the quarterly evolution of the Argentinean economy between 1980 and 2001. Results of the simulation exercise are summarized in the second column of Table $5 .{ }^{21}$ Panel A compares data and simulated moments for the statistics that were not directly targeted by the calibration exercise while Panel B reports results for the moments that were directly addressed by the simulation exercise.

The model predicts an average default rate of $2.5 \%$, which is equal to the one observed in the data. While the model underestimates the size of aggregate and domestic debt-

\footnotetext{
${ }^{21}$ Table 8 in Appendix lists the data sources for each moment analyzed.
} 
Figure 3. Public Debt Pricing Function
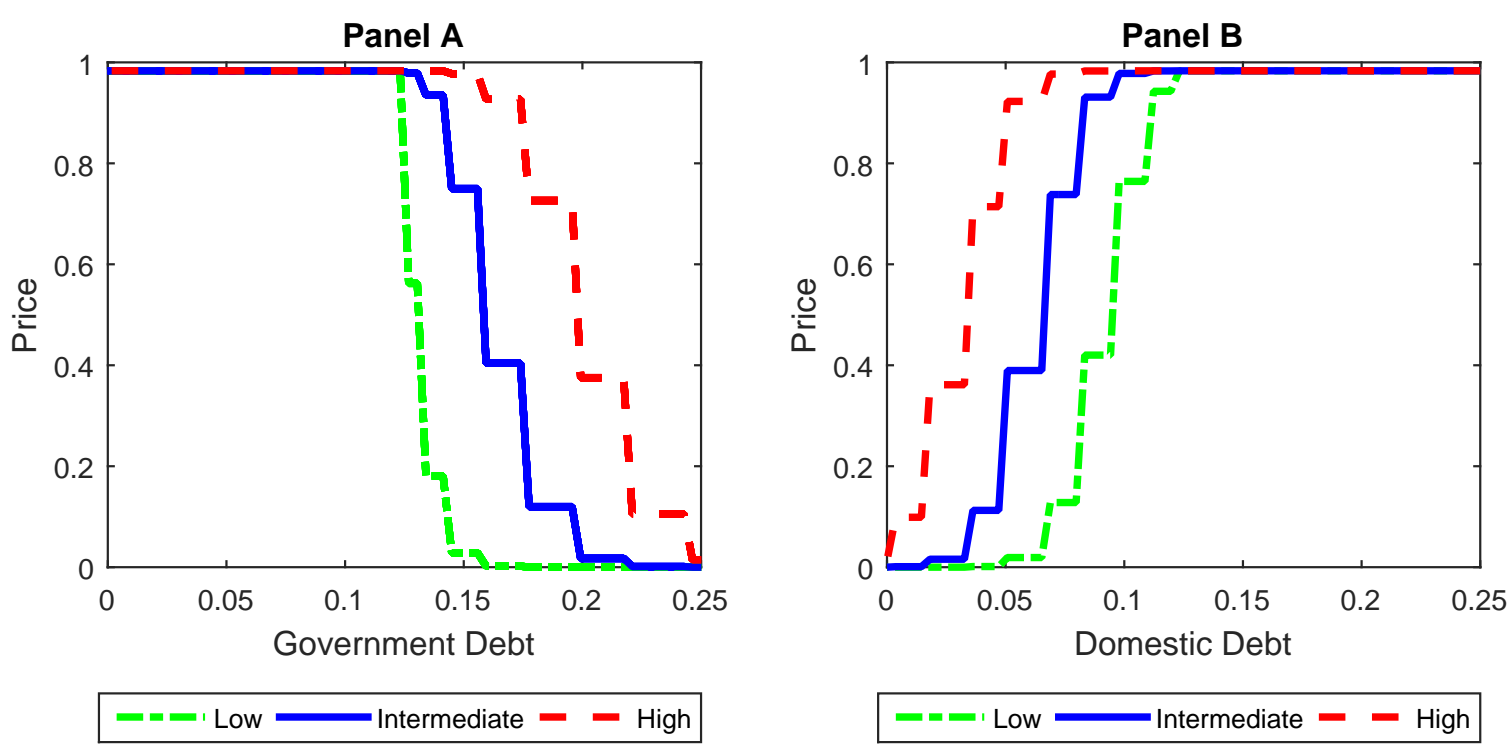

Panel A in Figure 3 plots government debt price as a function of total government debt (horizontal axis) for three different productivity levels holding domestic debt constant. Panel $\mathrm{B}$ draws prices as a function of domestic debt (horizontal axis) for three different productivity levels holding total government debt constant.

$15 \%$ and $0.09 \%$ in the model, respectively, and $48 \%$ and the $28 \%$ in the data - the average internal-external composition of debt is predicted accurately: $56 \%$ in the model and $58 \%$ in the data. ${ }^{22}$ The model also captures about half of the observed average spread between the Argentinean 5-year bonds and the five-year treasury bills. Turning to the second moments, the model matches broadly well the relative volatility of consumption and output and the negative quarterly correlation between the spread and both output and consumption.

Data about credit supply $L$ and debt composition $B^{H} / B$ are only available at the yearly frequency. The correlation between spreads and credit supply, as well as the correlation

\footnotetext{
${ }^{22} \mathrm{~A}$ key challenge in the sovereign default literature is to simultaneously match the high default frequency observed in the data and the high debt-to-GDP ratios. In quantitative models of sovereign defaults á la Eaton and Gersovitz (1981) there is a tension between the probability of default and the size of government debt - the higher the former, the lower the latter. The introduction of domestic debt reduces the tension between default rates and debt to GDP ratios and improves the quantitative performance of the model with respect to benchmark models. Still, the predicted debt-to-GDP ratio is far from the observed one in this particular calibration of the model. Lower discount rates generate debt levels that are closer to empirics.
} 
Table 5. Simulations

\begin{tabular}{lccc}
\hline \multicolumn{4}{c}{ Panel A: Non Targeted Moments } \\
Moments & Data & Model CE & Model EF \\
\hline \hline Mean Default Rate & $2.5 \%$ & $2.5 \%$ & $1.7 \%$ \\
Mean Debt/GDP ratio & 0.48 & 0.15 & 0.21 \\
Mean Domestic Debt/GDP ratio & 0.28 & 0.09 & 0.12 \\
Mean Internal/External Debt ratio & 0.58 & 0.56 & 0.57 \\
Mean Spread & 1,025 & 530 & 181 \\
& & & \\
$\sigma(c) / \sigma(y)$ & 1.40 & 1.03 & 1.06 \\
$\rho($ spread, $y)$ & -0.61 & -0.40 & -0.37 \\
$\rho($ spread, $)$ & -0.66 & -0.33 & -0.33 \\
& & & \\
$\rho(L$, spread $)$ & -0.55 & -0.50 & -0.70 \\
$\rho\left(B^{H} / B, y\right)$ & 0.54 & 0.32 & 0.25 \\
$\rho\left(B^{H} / B\right.$, spread $)$ & -0.24 & -0.14 & -0.18 \\
\hline Behavior around default: & & & \\
Mean GDP loss & $-14 \%$ & $-16 \%$ & $-26 \%$ \\
Mean Credit contraction & $-27 \%$ & $-22 \%$ & $-38 \%$ \\
\hline \hline
\end{tabular}

Table 5 reports moments obtained from model simulation. The first column contains the empirical moments while the second and third columns report moments obtained simulating the economy in the competitive equilibrium and in the efficient equilibrium, respectively. Moments are obtained simulating the model 100 times for 10,000 periods and averaging across the simulations. All variables are logged (except for ratios and spreads) and detrended. The variance of $\mathrm{X}$ is indicated as $\sigma(X)$; the correlation between $\mathrm{X}$ and $\mathrm{Y}$ is indicated as $\rho(X, Y)$.

between debt composition and both output and spreads, are therefore evaluated at the yearly frequency. The model reproduces the negative correlation between government spreads and credit supply that is observed in the data. The supply of credit to the private sector falls when yields are high. This is the crowding-out effect discussed by Ardagna et al. (2004) and 
Evans (1985). ${ }^{23}$ The model also replicates the negative correlation between spreads and the domestic debt-to-total debt ratio observed in the empirics. Spreads are high when domestic holdings of government debt are small.

Finally, I evaluate the performance of the model at predicting the evolution of output and credit around default. In the first quarter of 2002, following the sovereign default episode of December 2001, the Argentinean economy contracted $14 \%$ and credit supply contracted $27 \%$. The model matches these two regularities broadly well. Output is predicted to drop $16 \%$ in the year following the default episode, while credit is expected to contract $22 \%$. Figure 6 in Appendix A depicts the evolution of credit, output, and other variables of interest around default.

\subsection{Sensitivity Analysis}

In this section, I perform a sensitivity analysis to gain a better understanding of how a set of key moments react to changes in the parameters. Table 6 summarizes the findings of this exercise.

First, I investigate how the key moments react to changes in the working capital parameter $\gamma$. Parameter $\gamma$ regulates the demand for credit in the economy. When $\gamma$ is low, the size of the domestic credit market is smaller and the contraction of investors' balance sheets upon default is less harmful to the economy. It is therefore not surprising that smaller levels of $\gamma$ are associated with higher default risk and lower debt-to-GDP ratios in equilibrium. The opposite is true when $\gamma$ is high.

Second, I evaluate the model response to changes in the re-entry probability $\lambda$. As $\lambda$ increases from 0.2 to 0.35 , the average duration of the financial autarky decreases from 5 quarters to 3 quarters, making the default option more appealing. Higher $\lambda$ values are associated with higher default rates, while lower $\lambda$ values are associated with lower default risk and an improved sustainability of government debt.

I also check how the key moments react to changes of the parameters $\phi_{0}$ and $\phi_{1}$ in the

\footnotetext{
${ }^{23}$ The model also predicts that the quarterly correlation between the interest rates on domestic loans $r^{L}$ and spreads is positive. This is consistent with the empirical finding that borrowing costs rise for the private sector when spreads are higher. Finally, the correlation between output and $r^{L}$ is negative when spreads are low meaning that, absent the risk of default, interest rates on credit are procyclical, as suggested by Becker and Ivashina (2011).
} 
Table 6. Sensitivity Analysis

\begin{tabular}{lccccccc}
\hline \hline & Default Rate & $B / Y$ & $B^{H} / Y$ & $B^{H} / B$ & $L / Y$ & \% GDP loss & \% Credit fall \\
\hline \hline Data & $2.5 \%$ & 0.48 & 0.28 & 0.58 & 0.25 & $-14 \%$ & $-27 \%$ \\
Benchmark & $2.5 \%$ & 0.15 & 0.09 & 0.56 & 0.31 & $-16 \%$ & $-22 \%$ \\
\hline \multicolumn{7}{c}{ W-K constraint. Benchmark value: $\gamma=0.353$} \\
$\gamma=0.3$ & $4.4 \%$ & 0.10 & 0.06 & 0.55 & 0.27 & $-15 \%$ & $-19 \%$ \\
$\gamma=0.4$ & $0.8 \%$ & 0.20 & 0.12 & 0.59 & 0.35 & $-18 \%$ & $-24 \%$ \\
\hline \multicolumn{7}{c}{ Re-entry Prob. Benchmark value: $\lambda=0.2$} \\
$\lambda=0.15$ & $1.9 \%$ & 0.16 & 0.09 & 0.54 & 0.31 & $-18 \%$ & $-24 \%$ \\
$\lambda=0.35$ & $3.1 \%$ & 0.14 & 0.09 & 0.61 & 0.31 & $-9 \%$ & $-19 \%$ \\
\hline \multicolumn{7}{c}{ Cost parameter. Benchmark value: $\phi_{0}=-35$} \\
$\phi_{0}=-33$ & $2.0 \%$ & 0.17 & 0.10 & 0.56 & 0.31 & $-20 \%$ & $-28 \%$ \\
$\phi_{0}=-37$ & $3.4 \%$ & 0.13 & 0.07 & 0.57 & 0.31 & $-16 \%$ & $-21 \%$ \\
\hline \multicolumn{7}{c}{ Cost parameter. Benchmark value: $\phi_{1}=-116$} \\
$\phi_{1}=106$ & $3.4 \%$ & 0.12 & 0.07 & 0.60 & 0.31 & $-7 \%$ & $-14 \%$ \\
$\phi_{1}=120$ & $1.9 \%$ & 0.16 & 0.09 & 0.56 & 0.30 & $-19 \%$ & $-26 \%$ \\
$\psi=0.08$ & Capital Constraint Parameter. Benchmark value: $\psi=0.13$ & \\
$\psi=0.17$ & $1.7 \%$ & 0.18 & 0.10 & 0.57 & 0.33 & $-19 \%$ & $-27 \%$ \\
\hline \hline
\end{tabular}

Table 6 compares key moments obtained by simulating the model economy for a number of different parameters. Moments are obtained by simulating the model 100 times over 10,000 periods and averaging across simulations. Moments reported in the columns are the average default rate, the average debt-to-GDP ratio $B / Y$, the average domestic debt-to-GDP ratio $B^{H} / Y$, the average domestic debt-to-total debt ratio $B^{H} / B$, the average credit-to-GDP ratio $L / Y$, the average GDP loss, and the average credit contraction upon default.

cost function $\Phi(\mathcal{S})$. These two parameters crucially determine the substitutability between government bond holdings and fresh equity. When bank recapitalization is cheap, meaning that $\phi_{0}$ and $\phi_{1}$ are low, households can easily compensate banks for the losses caused by a default. In this case, default costs are smaller and incentives to default are higher as it is testified by the higher default frequency. Equilibrium debt-to-GDP ratios become smaller as the government debt becomes riskier.

Finally, I evaluate how the set of key moments changes when I alter parameter $\psi$, which regulates the tightness of the capital requirement in equation (16). When $\psi$, is small the 
capital requirement becomes tighter and the risk weight on private loans relative to government bonds increases. ${ }^{24}$ In equilibrium, domestic investors purchase more government bonds and thus the incentive of governments to default is smaller.

\section{Normative Analysis}

\subsection{Externality and Under-borrowing}

Figure 4. Domestic Debt: Policy Functions and Distributions
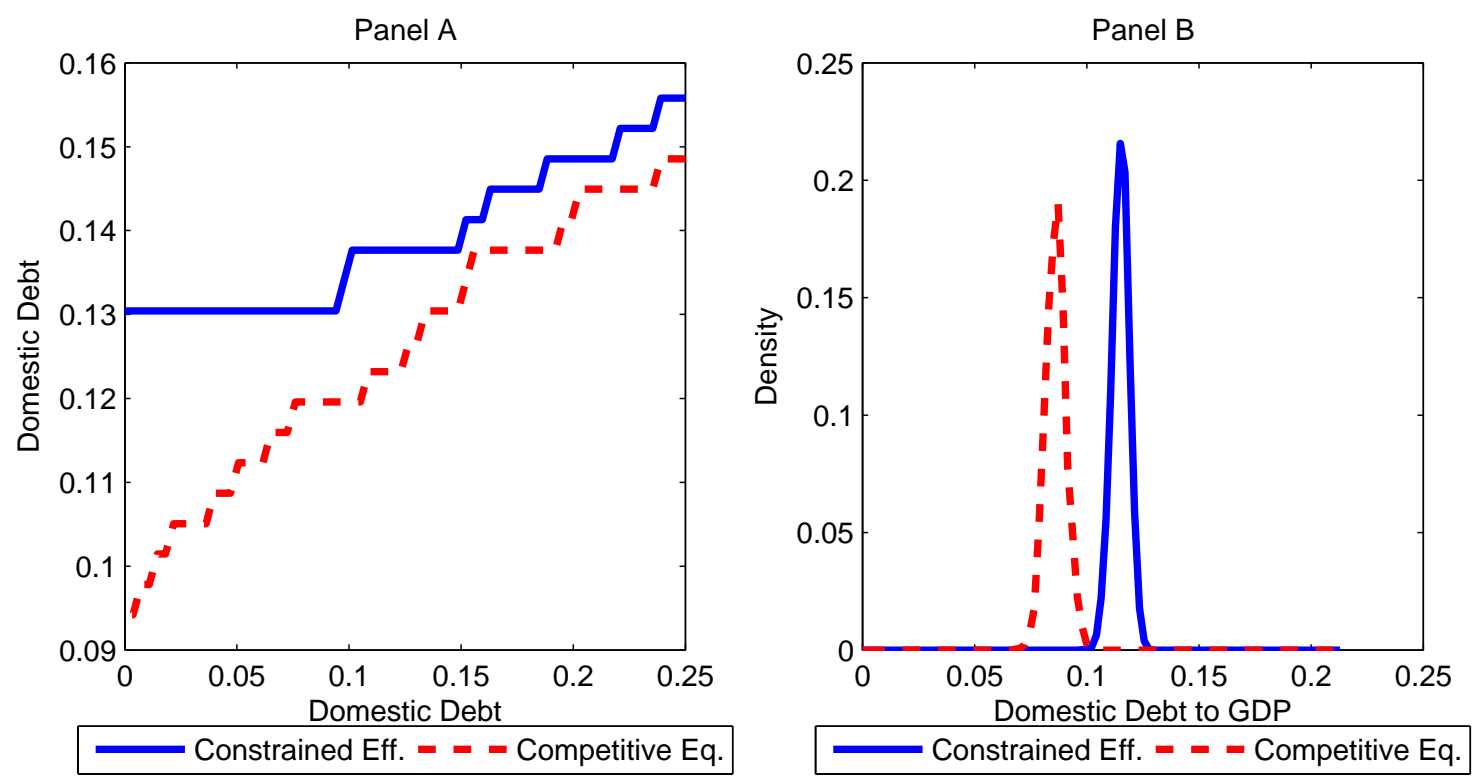

Panel A in Figure 4 compares the domestic debt policy functions in the competitive equilibrium and in the constrained efficient equilibrium. Panel B compares the distribution of domestic debt-to-GDP ratios in the competitive and in the constrained efficient equilibria.

Panel A in Figure 4 compares the policy functions for domestic holdings of government debt in the competitive equilibrium and in the constrained efficient equilibrium. Domestic holdings of government debt are inefficiently low in the competitive equilibrium. The inefficiency

\footnotetext{
${ }^{24}$ Recall the risk weight on domestic government bonds is constant and equal to zero.
} 
is caused by the existence of the pecuniary externality discussed in Section 5. Panel B in Figure 4 compares the predicted distributions of the domestic debt-to-GDP ratios in the competitive equilibrium and in the constrained efficient one. The domestic debt-to-GDP ratio is about $30 \%$ lower, on average, in the competitive equilibrium than in the efficient allocation.

The suboptimal management of domestic debt distorts government borrowing terms. The government faces worse borrowing terms in the competitive equilibrium than in the efficient allocation and this affects the management of aggregate government debt. Panel A in Figure 5 compares the policy functions for government debt in the two equilibria. The government issues an inefficiently low quantity of debt in the competitive equilibrium as a result of the pecuniary externality. Domestic investors lend too little to the government leading to under-borrowing in the sovereign debt market. This is also reflected in the distribution of the debt-to-GDP ratio that is reported in Panel B. Government debt-to-GDP ratio is about $0.25 \%$ lower, on average, in the competitive equilibrium than in the efficient allocation.

The last column in Table 5 contains simulated moments for the model economy in the constrained efficient equilibrium. The optimal management of domestic debt reduces default risk from $2.5 \%$ to $1.7 \%$ and improves government borrowing terms. The average spread falls from 530 basis points to 181 basis points. The debt-to-GDP ratio increases from $15 \%$ to $21 \%$, while the domestic debt-to-GDP ratio increases from $9 \%$ to $12 \%$. The composition of debt remains fairly stable and the domestic share of total government debt only changes from $56 \%$ to $57 \%$. While defaults happen at a lower frequency, their consequences are more severe. The contraction of both output and credit upon default is sharper. This is explained by two concurrent factors. On the one hand, governments are less prone to default and therefore defaults only happen with very bad productivity shocks. On the other hand, defaults involve larger quantities of debt, as domestic and external debt are larger. Figure 6 in Appendix A compares the evolution of a number of relevant variables around default in the competitive equilibrium and in the constrained efficient one.

\subsection{Optimal Pigouvian Subsidy}

Domestic investors fail to achieve the social optimum, as they do not internalize the consequences of their own decisions on the price $q$ of government debt. Investors under-lending leads to government under-borrowing, high default rates, and high government yields. Gov- 
Figure 5. Government Debt: Policy Functions and Distributions
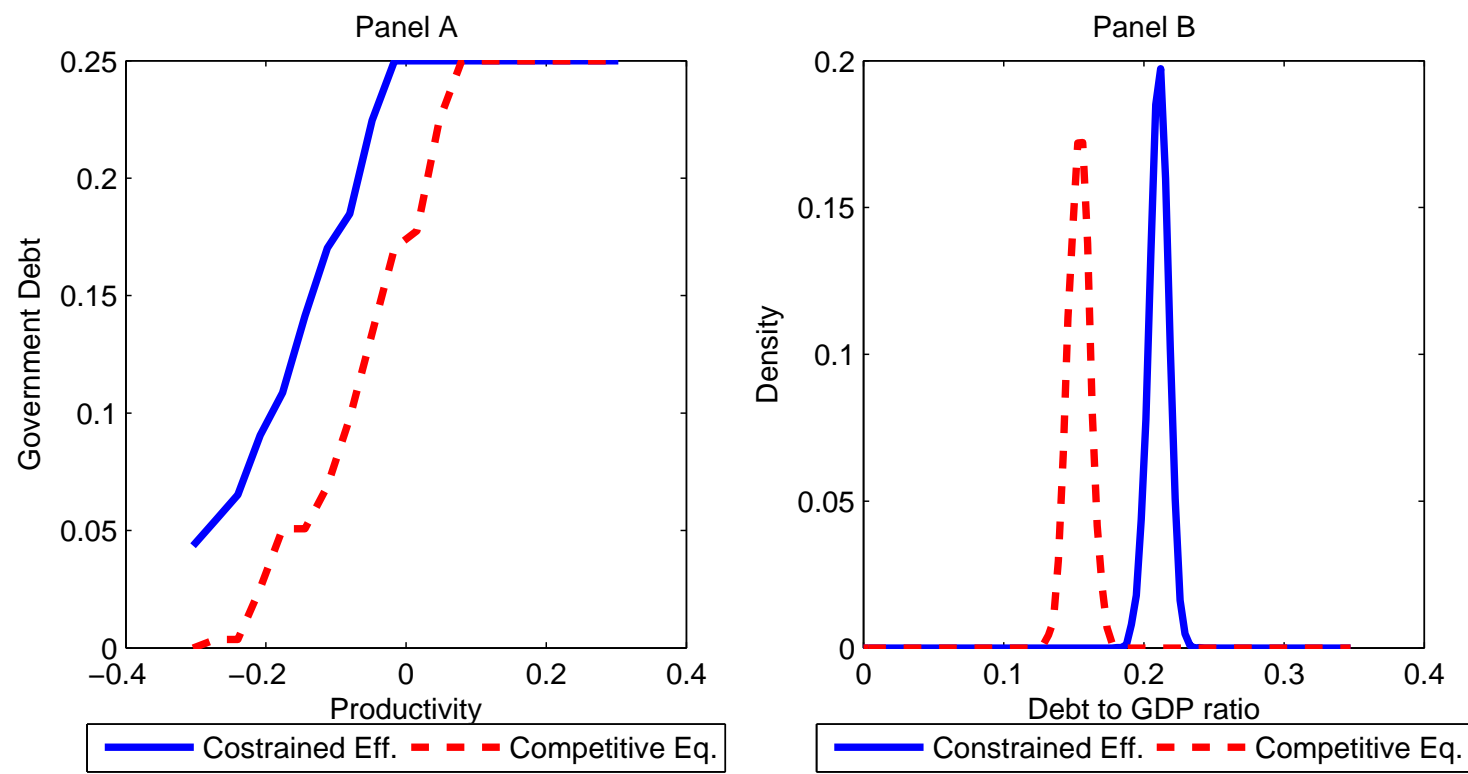

Panel A in Figure 5 compares the government debt policy functions in the competitive equilibrium and in the constrained efficient one. Panel B compares the distribution of debt -to-GDP ratios in the competitive and in the constrained efficient equilibria.

ernment intervention, however, can restore optimality by introducing a Pigouvian subsidy scheme $\tau$ that restores efficiency.

Let $\tau$ be a Pigouvian subsidy on domestic holdings of government debt. The budget constraint (28) of the household becomes

$$
c=w N+r^{L} l+b^{H}-(q-\tau) b^{\prime H, C E}-\phi(\mathcal{S})+T .
$$

Solving again the maximization problem of the household (19) by replacing constraint (28) with (56), the first-order condition with respect to domestic bond holding $B^{\prime H}$ becomes

$$
B^{\prime H}: q-\tau=\beta E \frac{\left(c^{\prime}-\frac{N^{\prime \omega}}{\omega}\right)^{-\sigma}}{\left(c-\frac{N^{\omega}}{\omega}\right)^{-\sigma}}\left[1+z^{\prime} \frac{\partial N^{\prime}}{\partial B^{\prime H}}\right] .
$$


The optimal Pigouvan subsidy that eliminates the externality is

$$
\tau=\frac{\partial q}{\partial B^{\prime H}}\left(B^{\prime}-B^{\prime H}\right)
$$

The Pigouvan subsidy scheme crucially depends on the sensitivity of government debt prices to domestic bond holdings: $\frac{\partial q}{\partial B^{\prime H}}$. When government yields are not influenced by the size of domestic debt, the optimal Pigouvian subsidy is zero.

Table 7. Optimal Tax Rate: Simulations

\begin{tabular}{lccccc}
\hline \hline & Mean $\tau$ & $\rho(\tau, y)$ & $\rho(\tau$, spread $)$ & W. Gain & max W. Gain \\
\hline \hline Model Simulations: & 0.31 & -0.37 & 0.44 & $1.4 \%$ & $8 \%$ \\
\hline \hline
\end{tabular}

Table 7 reports moments for the optimal tax rate $\tau$. Moments are obtained simulating the model 100 times for 10,000 periods and averaging across the simulations.

Key moments for the optimal prudential subsidy scheme and the associated welfare gains are summarized in Table 7. The average optimal subsidy rate is 0.31 . Subsidies are more generous when the economy is doing badly and when spreads are high. The average welfare gain of achieving the constrained efficient equilibrium is $1.4 \%$, measured in permanent units of consumption. Welfare gains of achieving the efficient allocation are typically small, while in this case they appear to be quite large. ${ }^{25}$ The reason is that, moving from the competitive equilibrium to the efficient allocation, the economy improves along three dimensions. First, consumption smoothing is improved. As the government gains better access to international financial markets, it can smooth fluctuations in the business cycle more effectively. Second, as the probability of default drops, the economy experiences fewer sovereign debt crises. Finally, in the efficient allocation, domestic holdings of government debt are larger and so are credit and output levels.

\footnotetext{
${ }^{25}$ Bianchi (2011), for instance, evaluates the welfare gains of eliminating over-borrowing in small open economies and finds that the average welfare gain is only $0.1 \%$.
} 


\section{Conclusions}

The academic and policy debate about the sustainability of government debt concentrates on debt size and on the economic cycle to quantify the risk of default. While these two dimensions are certainly crucial to determine the risk of default, the domestic versus external composition of debt is equally important. In particular empirical evidence suggests that (i) domestic debt is big; (ii) domestic defaults happen rather often and (iii) output and (iv) credit contract strongly around domestic defaults episodes. Based on these regularities, I construct a dynamic stochastic general equilibrium model with endogenous default risk á la Eaton and Gersovitz (1981), which also includes domestic debt, and I calibrate it to match the quarterly evolution of the Argentinean economy.

I show that the composition of debt matters in assessing the sustainability of public balances. Domestic debt interacts with default costs and reduces government incentives to default. Consequently, I claim that the optimal management of government debt should not be limited to the management of debt size, but should also target debt composition. This is especially true in light of the fact that markets are not able to achieve the efficient debt composition autonomously. 


\section{References}

Aguiar, Mark and Gita Gopinath, "Defaultable Debt, Interest Rates and the Current Account," Journal of International Economics, June 2006, 69 (1), 64-83.

Albertazzi, Ugo, Tiziano Ropele, Gabriele Sene, and Federico Maria Signoretti, "The Iimpact of the Sovereign Debt Crisis on the Activity of Italian Banks," Journal of Banking $\&$ Finance, 2014, 46 (C), 387-402.

Ardagna, Silvia, Francesco Caselli, and Timothy Lane, "Fiscal Discipline and the Cost of Public Debt Service: Some Estiames for OECD Countries," Working Paper Series 0411, European Central Bank November 2004.

Arellano, Cristina, "Default Risk and Income Fluctuations in Emerging Economies," American Economic Review, 2008, 98 (3), 690-712.

- and Ananth Ramanarayanan, "Default and the Maturity Structure in Sovereign Bonds," Journal of Political Economy, 2012, 120 (2), 187-232.

Arteta, Carlos and Galina Hale, "Sovereign debt crises and credit to the private sector," Journal of International Economics, January 2008, 74 (1), 53-69.

Beck, Thorsten, Asli Demirguc-Kunt, and Ross Levine, "Financial Institutions and Markets across Countries and over Time - Data and Analysis," Policy Research Working Paper Series 4943, The World Bank May 2009.

Becker, Bo and Victoria Ivashina, "Cyclicality of Credit Supply: Firm Level Evidence," Working Paper 17392, National Bureau of Economic Research September 2011.

Bianchi, Javier, "Overborrowing and Systemic Externalities in the Business Cycle," American Economic Review, December 2011, 101 (7), 3400-3426.

Bocola, Luigi, "The Pass-Through of Sovereign Risk," Working Papers 722, Federal Reserve Bank of Minneapolis April 2015.

Bofondi, Marcello, Luisa Carpinelli, and Enrico Sette, "Credit Supply during a Sovereign Debt Crisis," Temi di discussione (Economic working papers) 909, Bank of Italy, Economic Research and International Relations Area April 2013.

Bolton, Patrick and Olivier Jeanne, "Sovereign Default Risk and Bank Fragility in Financially Integrated Economies," IMF Economic Review, June 2011, 59 (2), 162-194. 
Borensztein, Eduardo and Ugo Panizza, "The Costs of Sovereign Default," IMF Staff Papers, November 2009, 56 (4), 683-741.

Broner, Fernando, Aitor Erce, Alberto Martin, and Jaume Ventura, "Sovereign Debt Markets in Turbulent Times: Creditor Discrimination and Crowding-Out Effects," Journal of Monetary Economics, 2014, 61 (C), 114-142.

_, Alberto Martin, and Jaume Ventura, "Sovereign Risk and Secondary Markets," American Economic Review, 2010, 100 (4), 1523-1555.

Brutti, Filippo, "Sovereign Defaults and Liquidity Crises," Journal of International Economics, May 2011, 84 (1), 65-72.

DePaoli, Bianca, Glenn Hoggarth, and Victoria Saporta, "Output costs of sovereign crises: some empirical estimates," Bank of England working papers 362, Bank of England February 2009.

D'Erasmo, Pablo and Enrique G. Mendoza, "Distributional Incentives in an Equilibrium Model of Domestic Sovereign Default," Working Paper 19477, National Bureau of Economic Research September 2013.

_ , Bora Durdu, and Emine Boz, "Sovereign Risk and Bank Balance Sheets: The Role of Macroprudential Policies," Technical Report 2014.

Eaton, Jonathan and Mark Gersovitz, "Debt with Potential Repudiation: Theoretical and Empirical Analysis," Review of Economic Studies, April 1981, 48 (2), 289-309.

Evans, Paul, "Do Large Deficits Produce High Interest Rates?," American Economic Review, March 1985, 75 (1), 68-87.

Gelos, R. Gaston, Ratna Sahay, and Guido Sandleris, "Sovereign Borrowing by Developing Countries: What Determines Market Access?," Journal of International Economics, March 2011, 83 (2), 243-254.

Gennaioli, Nicola, Alberto Martin, and Stefano Rossi, "Sovereign Default, Domestic Banks, and Financial Institutions," Journal of Finance, 04 2014, 69 (2), 819-866.

Guerrieri, Luca, Matteo Iacoviello, and Raoul Minetti, "Banks, Sovereign Debt, and the International Transmission of Business Cycles," NBER International Seminar on Macroeconomics, 2013, 9 (1), $181-213$. 
Hatchondo, Juan Carlos, Leonardo Martinez, and Horacio Sapriza, "Quantitative Properties of Sovereign Default Models: Solution Methods," Review of Economic Dynamics, October 2010, 13 (4), 919-933.

Hennessy, Christopher A. and Toni M. Whited, "Debt Dynamics," Journal of Finance, June 2005, 60 (3), 1129-1165.

Holmstrom, Bengt and Jean Tirole, "Private and Public Supply of Liquidity," Journal of Political Economy, February 1998, 106 (1), 1-40.

Kohlscheen, Emanuel, "Domestic vs. External Sovereign Debt Servicing: an Empirical Analysis," Working Paper, Coventry 2009.

Mendoza, Enrique G. and Javier Bianchi, "Overborrowing, financial crises and macroprudential taxes," Proceedings, 2010, (Oct).

- and Vivian Z. Yue, "A General Equilibrium Model of Sovereign Default and Business Cycles," The Quarterly Journal of Economics, 2012, 127 (2), 889-946.

Na, Seunghoon, Stephanie Schmitt-Grohe, Martin Uribe, and Vivian Z. Yue, "A Model of the Twin Ds: Optimal Default and Devaluation," CQER Working Paper 2015-1, Federal Reserve Bank of Atlanta April 2015.

Pescatori, Andrea, Damiano Sandri, and John Simon, "Debt and Growth: Is There a Magic Threshold?," IMF Working Papers 14/34, International Monetary Fund February 2014 .

Reinhart, Carmen M. and Kenneth S. Rogoff, "The Forgotten History of Domestic Debt," Working Paper 13946, National Bureau of Economic Research April 2008.

Sandleris, Guido, "The Costs of Sovereign Defaults: Theory and Empirical Evidence," 2012.

Sosa-Padilla, Cesar, "Sovereign Defaults and Banking Crises," Technical Report 2014.

Tauchen, George and Robert Hussey, "Quadrature-Based Methods for Obtaining Approximate Solutions to Nonlinear Asset Pricing Models," Econometrica, March 1991, 59 (2), 371-96. 


\section{A Tables and Graphs}

Table 8. Data Sources

\begin{tabular}{ll}
\hline \hline Variable & Data Source \\
\hline \hline$\sigma(c) / \sigma(y)$ & Arellano (2008) \\
$\rho($ spread, $y)$ & Arellano (2008) \\
$\rho($ spread, $c)$ & Arellano (2008) \\
Default Rate & Arellano (2008) \\
Domestic Credit Provided by the Financial Sector & World Bank (World Development Indicators) \\
Government to GDP ratio & World Bank (World Development Indicators) \\
Exposure rate & Financial Structure Database \\
Equity/Assets ratio & Financial Structure Database: ROA/ROE \\
Gross Domestic Product & World Bank (World Development Indicators) \\
Total Debt & Reinhardt and Rogoff "This Time is Different Database" \\
Domestic Debt & World Bank (Quarterly Public Sector Debt Database) \\
Domestic Debt (Advanced Economies) & Bruegel (Sovereign Bond Dataset) \\
External Debt & World Bank (International Debt Statistics) \\
External Debt (Argentina) & Arellano (2008) \\
Wage share of GDP (Argentina) & INDEC (Instituto Nacional de Estadistica y Censos) \\
US-Argentina Spread & Arellano (2008) \\
\hline \hline
\end{tabular}

Table 8 lists source databases for the moments reported in the quantitative analysis 
Table 9. Default Episodes

\begin{tabular}{|c|c|c|c|c|c|c|c|}
\hline Country & Domestic Default & External Default & Credit Data & Country & Domestic Default & External Default & Credit Data \\
\hline Argentina & $1982,1989,2001$ & 1982,2001 & yes & Jordan & & 1989 & no \\
\hline Belize & 2005 & $2005^{6}$ & yes & Morocco & & 1983 & yes \\
\hline Bolivia & 1983 & 1980,1986 & yes & Mexico & & 1982 & yes \\
\hline Brazil & 1986,1990 & 1983 & yes & Nigeria & & 1982 & yes \\
\hline Chile & & 1983 & no & Pakistan & & 1998 & yes \\
\hline Costa Rica & & 1981 & yes & Panama & & 1983 & yes \\
\hline Croatia & 1993 & & no & Peru & & 1983 & yes \\
\hline Domenican Rep. & 1982,2003 & 1982,2003 & yes & Paraguay & 2003 & 1986,2003 & yes \\
\hline Ecuador & 1999,2005 & $1982,1999,2005$ & yes & Romania & & 1986 & no \\
\hline El Salvador & 1981 & & yes & Russia & 1998 & & yes \\
\hline Egypt & & 1984 & yes & Trinidad \& Tob. & & 1988 & yes \\
\hline Grenada & 2004 & 2004 & yes & Turkey & & 1982 & no \\
\hline Guatemala & & 1986 & yes & Ukraine & 1998 & 1998 & no \\
\hline Indonesia & & 1998 & yes & Uruguay & 2003 & $1984,1990,2003$ & yes \\
\hline Jamaica & & 1981,1987 & yes & Venezuela & 1995 & $1983,1990,1995,2003$ & no \\
\hline
\end{tabular}

Table 9 reports the list of default episodes observed between 1980 and 2005. Following Reinhart and Rogoff (2008) and Kohlscheen (2009), I adopt Standard and Poor's identification of defaults. Whenever two defaults are separated by less than three years, I consider them a single default 
Figure 6. Dynamics around Default
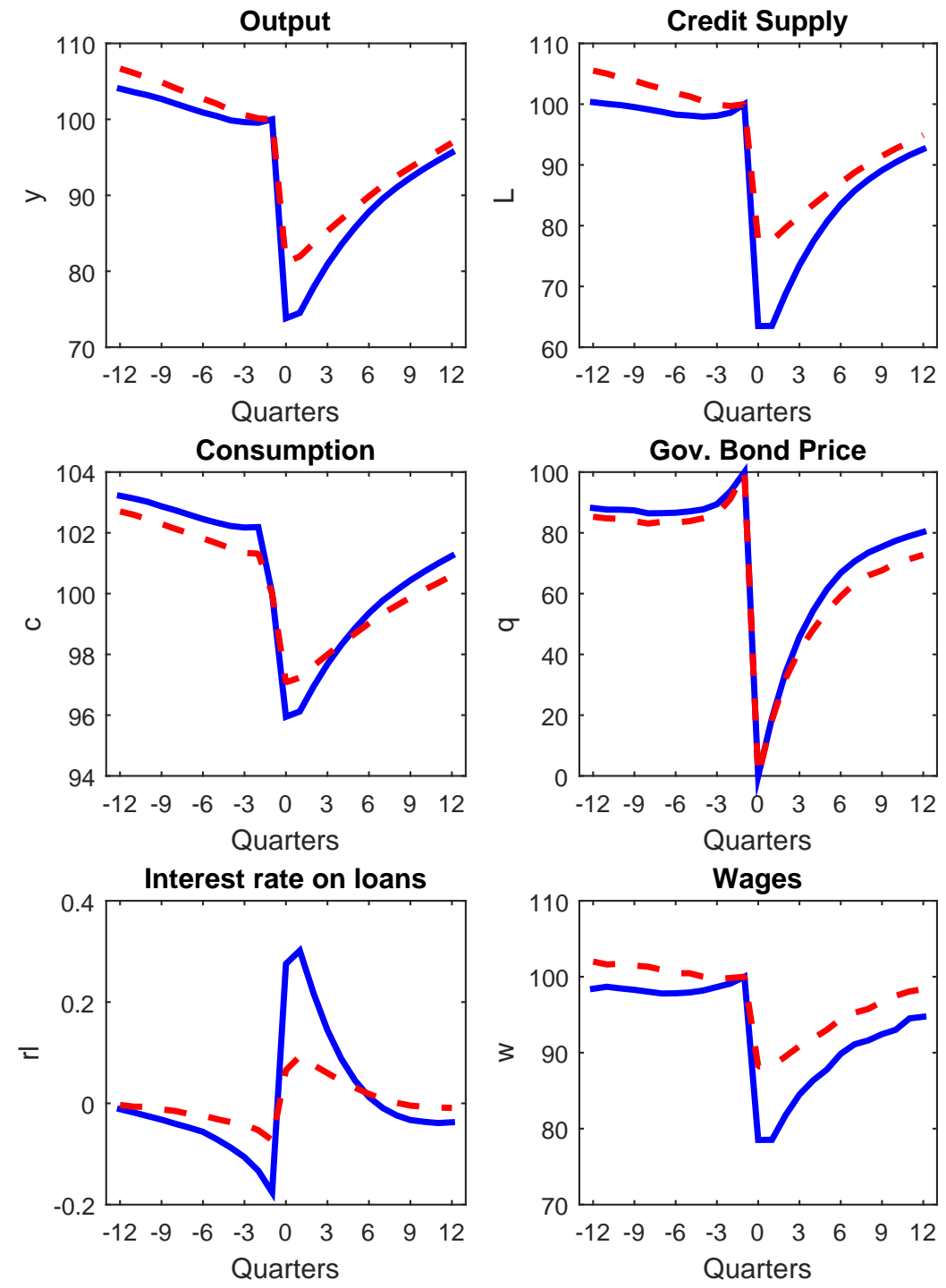

Figure 6 describes the average evolution of output, credit, consumption, government bonds price, interest rates on loans, and wages around default in the competitive equilibrium (blue solid lines) and in the constrained efficient equilibrium (red dashed lines). Time is on the horizontal axis and spans from 12 quarters before to 12 quarters after a sovereign default episode. Averages are computed over a sample of 197 simulated default episodes. 


\section{A.1 Solution Algorithm}

Following Hatchondo et al. (2010) equilibria are found by iterating the finite model backwards until convergence. In the terminal, period it is assumed that financial markets are closed as there is no need to transfer resources across time.

\section{Competitive Equilibrium}

1. Discretize the productivity shock $z$ using a quadrature method, as in Tauchen and Hussey (1991).

2. Set up the discrete grid reproducing the state space $\Omega=\left\{z \times B \times B^{H} \times b^{H}\right\}$.

3. Initialize households' value functions in the default scenario $V^{d}$ and in the non-default scenario $V^{\text {nd }}$ evaluating households' utilities in the terminal period of each point of $\Omega$.

4. Evaluate the default set in the terminal period comparing household's utilities in the default scenario and in the non-default scenario. Initialize government debt price $q\left(z, B^{\prime}, B^{\prime H}\right)$ accordingly.

5. Arbitrarily initialize the forecasting rule $B^{\prime H}=H\left(z, B, B^{H}\right)$, which is constant over individual domestic debt levels $b^{\prime H}$.

6. For every possible government choice $\left\{B^{\prime}\right.$, de $\left.f\right\}$, determine the household policy function $b^{\prime C E, H *}\left(z, B, B^{H}, b^{H}\right)$ that maximizes households' value function given the forecasting rule $B^{\prime H}=H\left(z, B, B^{H}\right)$ and the government debt price $q\left(z, B^{\prime}, B^{\prime H}\right)$.

7. Update the forecasting rule imposing the equilibrium condition $b^{\prime C E, H *}=B^{\prime C E, H *}=$ $H^{C E *}\left(z, B, B^{H}\right)$, ensuring that individual and aggregate choices coincide.

8. Derive the optimal policy function for government debt $B^{\prime C E *}$, which maximizes household's value function given the optimal choices of domestic agents $B^{\prime C E, H *}$ and the associated government debt price $q\left(z, B^{\prime}, B^{\prime C E, H *}\right)$.

9. Update the value functions of the household computing value functions at the optimum $V^{d}\left(z, B^{C E *}, B^{C E, H *}\right)$ and $V^{n d}\left(z, B^{C E *}, B^{C E, H *}\right)$.

10. Compare value functions in the default and in the non-default scenarios and determine the default set. Update government debt $q\left(z, B^{\prime C E *}, B^{\prime E F, H *}\right)$ price accordingly. 
11. Repeat steps 6 to 10 until value functions, government debt price, and forecasting rule have converged. Tolerance values are set to $1 e^{-6}$.

\section{Constrained Efficient Equilibrium}

1. Discretize the productivity shock $z$ using a quadrature method, as in Tauchen and Hussey (1991)

2. Set up the discrete grid reproducing the state space $\hat{\Omega}=\left\{z \times B \times B^{H}\right\}$.

3. Initialize household's value functions in the default scenario $V^{d}$ and in the non-default scenario $V^{n d}$ evaluating household's utilities in the terminal period of each point of $\hat{\Omega}$.

4. Evaluate the default set in the terminal period comparing household's utilities in the default scenario and in the non-default scenario. Initialize government debt price $q\left(z, B^{\prime}, B^{\prime H}\right)$ accordingly.

5. For every possible government choice $\left\{B^{\prime}\right.$, def $\}$, determine the household policy function $B^{\prime E F, H *}\left(z, B, B^{H}\right)$ that maximizes household's value function given the government debt price $q\left(z, B^{\prime}, B^{\prime H}\right)$.

6. Derive the optimal policy function for government debt $B^{\prime E F *}$, which maximizes household's value function given the optimal choices of domestic agents $B^{\prime E F, H *}$ and the associated government debt price $q\left(z, B^{\prime}, B^{\prime E F, H *}\right)$.

7. Compare value function in the default and in the non-default scenarios and determine the default set. Update government debt $q\left(z, B^{\prime E F *}, B^{\prime E F, H *}\right)$ price accordingly.

8. Repeat steps 5 to 7 until the value functions, government debt price, and forecasting rule have converged. Tolerance values are set to $1 e^{-6}$. 